\title{
The $7600\left({ }^{14} \mathrm{C}\right)$ year BP Kurile Lake caldera-forming eruption, Kamchatka, Russia: stratigraphy and field relationships
}

\author{
V.V. Ponomareva ${ }^{a, *}$, P.R. Kyle ${ }^{b}$ I.V. Melekestsev ${ }^{a}$, P.G. Rinkleff ${ }^{b}$, \\ O.V. Dirksen ${ }^{a}$, L.D. Sulerzhitsky ${ }^{c}$, N.E. Zaretskaia ${ }^{c}$, R. Rourke ${ }^{b}$ \\ a Institute of Volcanology and Seismology, Piip Blvd. 9, Petropavlovsk-Kamchatsky 683006, Russia \\ ${ }^{\mathrm{b}}$ Department of Earth and Environmental Science, New Mexico Institute of Mining and Technology, Socorro, NM 87801-4796, USA \\ ${ }^{\mathrm{c}}$ Geological Institute, Pyzhevsky per. 7, Moscow 119017, Russia
}

\begin{abstract}
The $7600{ }^{14} \mathrm{C}$-year-old Kurile Lake caldera-forming eruption (KO) in southern Kamchatka, Russia, produced a 7-km-wide caldera now mostly filled by the Kurile Lake. The KO eruption has a conservatively estimated tephra volume of $140-170 \mathrm{~km}^{3}$ making it the largest Holocene eruption in the Kurile-Kamchatka volcanic arc and ranking it among the Earth's largest Holocene explosive eruptions. The eruptive sequence consists of three main units: (I) initial phreatoplinian deposits; (II) plinian fall deposits, and (III) a voluminous and extensive ignimbrite sheet and accompanying surge beds and co-ignimbrite fallout. The KO fall tephra was dispersed over an area of $>3$ million $\mathrm{km}^{2}$, mostly in a northwest direction. It is a valuable stratigraphic marker for southern Kamchatka, the Sea of Okhotsk, and a large part of the Asia mainland, where it has been identified as a $\sim 6$ to $0.1 \mathrm{~cm}$ thick layer in terrestrial and lake sediments, $1000-1700 \mathrm{~km}$ from source. The ignimbrite, which constitutes a significant volume of the KO deposits, extends to the Sea of Okhotsk and the Pacific Ocean on either side of the peninsula, a distance of over $50 \mathrm{~km}$ from source. Fine co-ignimbrite ash was likely formed when the ignimbrite entered the sea and could account for the wide dispersal of the $\mathrm{KO}$ fall unit. Individual pumice clasts from the fall and surge deposits range from dacite to rhyolite, whereas pumice and scoria clasts in the ignimbrite range from basaltic andesite to rhyolite. Ignimbrite exposed west and south of the caldera is dominantly rhyolite, whereas north, east and southeast of the caldera it has a strong vertical compositional zonation from rhyolite at the base to basaltic andesite in the middle, and back to rhyolite at the top. Following the KO eruption, Iliinsky volcano formed within the northeastern part of the caldera producing basalt to dacite lavas and pyroclastic rocks compositionally related to the $\mathrm{KO}$ erupted products. Other post-caldera features include several extrusive domes, which form islands in Kurile Lake, submerged cinder cones and the huge silicic extrusive massif of Dikii Greben' volcano.
\end{abstract}

(C) 2004 Elsevier B.V. All rights reserved.

Keywords: caldera; explosive eruption; ignimbrite; Kamchatka; Kurile Lake; Holocene

* Corresponding author. Tel.: + 7-415-22-59194; fax: +7-41522-59130.

E-mail address: ponomareva@ginras.ru (V.V. Ponomareva).

\section{Introduction}

Arc volcanoes pose a significant hazard to society because of their number, explosiveness and frequency of eruptions. By documenting and dating past eruptions, and estimating their size and eruptive volumes, 
we can contribute to the global paleovolcanic record and provide a framework for further volcanological and petrologic studies.

Five large $(\mathrm{VEI}=5-7)$ explosive caldera-forming eruptions took place on the Kamchatka Peninsula during the Holocene. Three occurred at the Ksudach volcanic massif and the other two resulted in the formation of the Karymsky and Kurile Lake calderas (Braitseva et al., 1995, 1997a,b). Some Ksudach eruptions have been described (Braitseva et al., 1996; Bursik et al., 1993; Melekestsev et al., 1996; Volynets et al., 1999), but the larger Kurile Lake caldera-forming eruption has only received brief mention (Piip, 1947; Melekestsev et al., 1974; Braitseva et al., 1995, 1997a,b). Recent field work in the Kurile Lake area has collected new data on the deposits and allows us to reconstruct the eruptive history. Here we document the largest Holocene explosive eruption on the Kamchatka Peninsula, which resulted in the formation of the Kurile Lake caldera and produced an extensive ignimbrite deposit which has characteristics resembling the Taupo ignimbrite (Wilson, 1985). The eruption would have devastated the southern Kamchatka Peninsula and is likely to have had a short-term impact on the global climate. We describe the stratigraphy, distribution, age, composition and volume of the deposits from the eruption and reconstruct the eruptive sequence. New data allow us to re-consider the extent of tephra dispersal and discuss the characteristic features of the tephra that are helpful for its identification and correlation in distal sites. Petrologic evolution of the eruption will be considered in detail in a separate paper (Kyle et al., in preparation).

\section{Geologic background and previous studies}

Kurile Lake is located at the southern end of the Kamchatka Peninsula. The lake is $81 \mathrm{~m}$ above sea level and has an area of $76 \mathrm{~km}^{2}$. It drains into the Ozernaya River, which flows to the Sea of Okhotsk (Figs. 1 and 2). The lake and surrounds is a wilderness area and the rugged volcanic landscape is mostly covered with bush and forest vegetation. In mid-

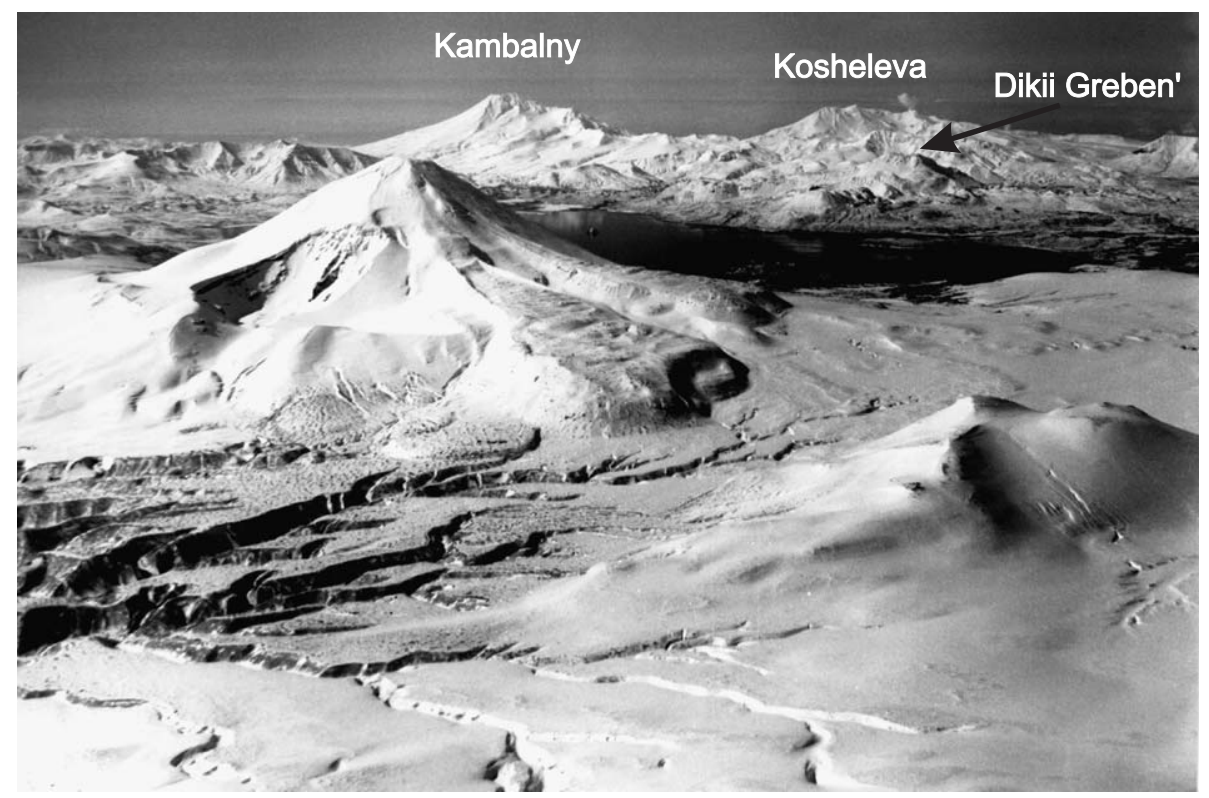

Fig. 1. View looking southwest of Kurile Lake and Iliinsky volcano from Zheltovsky volcano. Iliinsky volcano and the dissected surface of the Kurile Lake caldera ignimbrite are in the foreground. Iliinsky is located in a crater of the Late Pleistocene pre-lliinsky volcano (the rim of the crater can be seen at the break of slope to the left of Iliinsky and can be traced around before being buried by a young Iliinsky andesite lava flow). The large fresh crater on the center-left slope of Iliinsky formed in 1901 by a phreatic eruption. Kurile Lake is behind and to the right of Iliinsky. Dikii Greben' extrusive massif is on the right just across the Kurile Lake. The Holocene and Late Pleistocene Kambalny and Kosheleva volcanoes are in the background. Photo by Nikolai Smelov. 

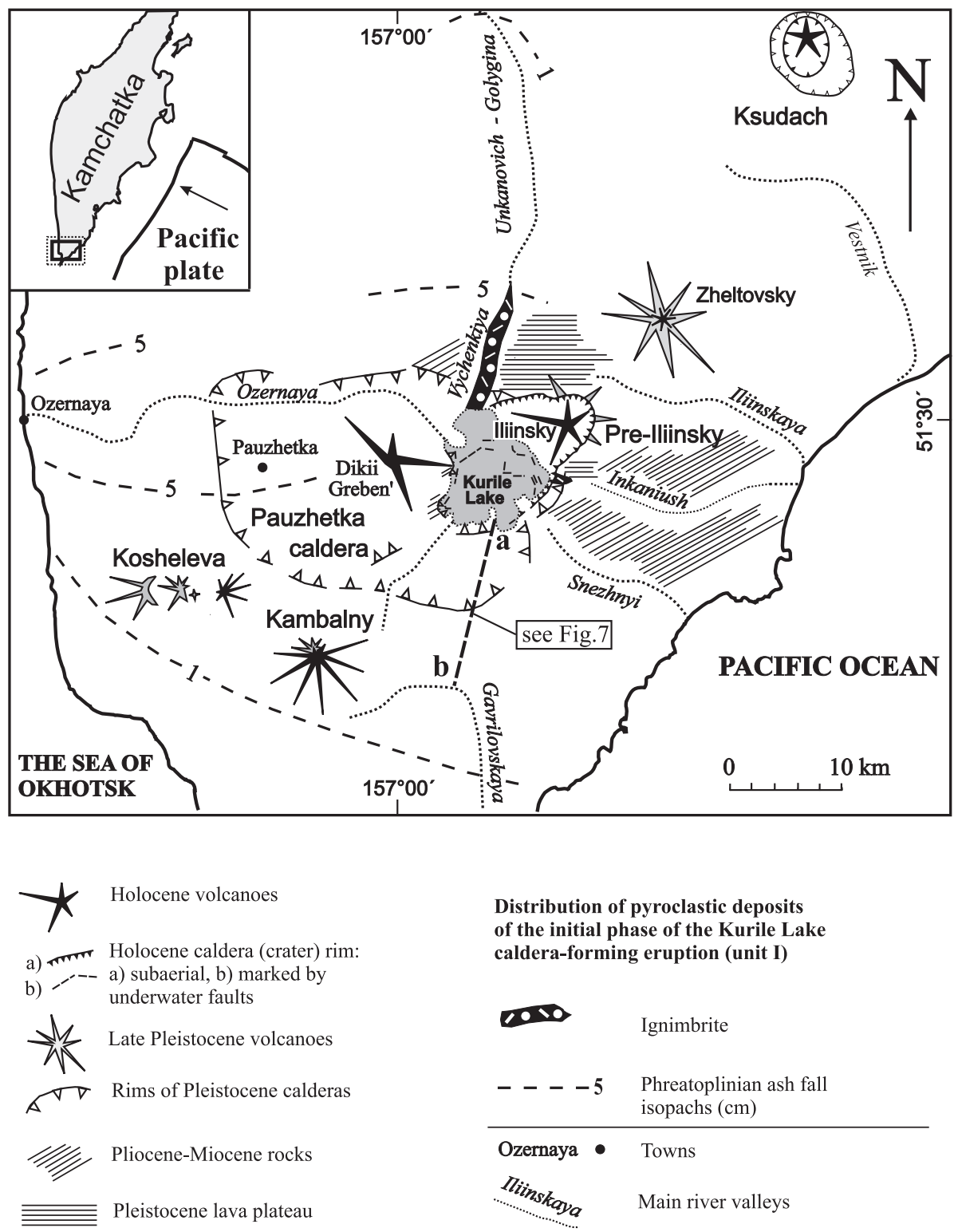

Fig. 2. Location map for the Kurile Lake region, South Kamchatka, and distribution of the basal unit (unit I) of the Kurile Lake caldera-forming eruption deposits. Dashed line $\mathrm{a}-\mathrm{b}$ south of the lake marks the profile shown in Fig. 7.

Pleistocene time, the area is believed to be an island separated from the Kamchatka Peninsula by a strait (Melekestsev et al., 1974).

Volcanism on the Kamchatka Peninsula results from subduction of the Pacific plate underneath the Okhotsk and North American plates at a rate of $\sim 8 \mathrm{~cm} /$ year (Geist and Scholl, 1994; Gorbatov et al., 1997). The 7-km-wide Kurile Lake caldera belongs to the subduction-related Eastern volcanic belt of Kamchatka. The belt lies $\sim 200 \mathrm{~km}$ inboard of the Kurile-Kamchatka trench and $100 \mathrm{~km}$ above the Wadati-Benioff zone (Gorbatov et al., 1997).

Volcanic eruptions in southern Kamchatka have been highly explosive. Four of the six Holocene 
eruptions in Kamchatka with tephra volumes greater than $10 \mathrm{~km}^{3}$ (Braitseva et al., 1997a) took place in southern Kamchatka. The Kurile Lake caldera is 50 $\mathrm{km}$ south of the Ksudach caldera complex which experienced two Late Pleistocene and three Holocene caldera-forming eruptions (Melekestsev et al., 1996). Kurile Lake is surrounded by the Late Pleistocene-Holocene volcanoes Zheltovsky, Iliinsky, Dikii Greben', Kosheleva, and Kambalny which are located only $12-18 \mathrm{~km}$ from one another (Figs. 1 and 2). Recent eruptions include Zheltovsky in 1923, Illinsky in 1901, Kosheleva, and probably, Kambalny, in the 17 th century (Novograblenov, 1932).

The Holocene and Pleistocene volcanic deposits rest on Pliocene to Miocene volcanic and sedimentary rocks (Florensky and Bazanova, 1991). Pleistocene volcanism included the formation of lava plateaus, several calderas, and several stratovolcanoes including the pre-Iliinsky somma-volcano, which encloses modern Iliinsky (Figs. 1 and 2). The existence of a Late Pleistocene caldera within a larger mid-Pleistocene Pauzhetka caldera has been proposed but the existence of this caldera is still being debated (Melekestsev et al., 1974, 1991). At least two partly superimposed caldera scarps of Pleistocene age can be identified near the lake (Fig. 2), that cut an Early Pleistocene lava plateau and Pliocene-Miocene rocks. Even if this Late Pleistocene caldera did not exist there was likely to have been a lake filled depression at the time of the Kurile Lake caldera-forming eruption (Bondarenko, 1991). The only younger Pleistocene volcanic feature (cut by the Holocene caldera scarps) is the decapitated Late Pleistocene pre-Iliinsky volcano, which is mostly buried under younger deposits but is manifested in the topography (Fig. 1). In addition, some pre-Iliinsky rocks are exposed in the walls of the 1901 crater.
Widespread outcrops of white pumice around Kurile Lake, some more than $150 \mathrm{~m} \mathrm{high,} \mathrm{caught} \mathrm{the}$ attention of native settlers who called them "Kutkh's boats" (Kutkh was a hero of local folklore), since the shape of the vertical ribs, formed by erosion and possibly fumarolic induration, resembled huge overturned boats put out to dry (Fig. 3D,E). Piip (1947) began reconnaissance volcanological studies in South Kamchatka and suggested that the eruption of pumice was associated with a tectonic depression centered within Kurile Lake. This idea was supported by Braitseva et al. (1965), who determined the pumice was a pyroclastic flow deposit erupted during the Kurile Lake caldera-forming eruption. Some researchers attributed the pumice deposits in different valleys to individual fissure vents and discounted the existence of a caldera (e.g. Masurenkov, 1980). Radiocarbon dates for the Kurile Lake caldera deposits, which are discussed in detail below, give an age of about 7600 years BP (Zaretskaia et al., 2001). Braitseva et al. (1997b) recognized widespread tephra fall from the Kurile Lake eruption over much of southern Kamchatka, and Melekestsev et al. (1991) identified it in the Magadan region on mainland Asia. These findings showed that the Kurile Lake caldera-forming eruption (coded KO) was the largest Holocene eruption in Kamchatka and the most important in "a century" of volcanic catastrophes (6600-6400 BC), which included two caldera-forming and numerous other eruptions (Braitseva et al., 1995; Melekestsev et al., 1998). Bathymetric and other geophysical studies have detailed the topography and main structures of the Kurile Lake depression (Zubin et al., 1982; Bondarenko, 1991). However, proximal deposits of the KO eruption, their stratigraphy, distribution and composition have never been described before.

The KO eruption sequence rests on a 5-20 cm thick paleosol, which represents an $~ 1500$-year-long period of volcanic quiescence in southern Kamchatka

Fig. 3. Various facies of the Kurile Lake caldera-forming eruption (KO) deposits. Roman numbers denote eruptive units. (A) Unit I: basal phreatoplinian ash, overlain by pumice fall deposit (unit II). Pauzhetka town, $20 \mathrm{~km}$ west of the lake. Photo by Philip Kyle. (B) Lower part of the KO eruptive sequence, Pervaya Severnaya River, close to northwestern shore of the lake. Pumice fallout, unit II, underlain by ash of the initial phase of the eruption (unit I) and overlain by the ignimbrite (unit III). Photo by Oleg Dirksen. (C) Welded ignimbrite on the Pulomynk Peninsula, western shore of the lake. Exposure is about $15 \mathrm{~m}$ high. Photo by L.D. Sulerzhitsky. (D) "Kutkh's boats"-a 100-m-high exposure of white silicic ignimbrite in the Ozernaya River valley. Photo by L.D. Sulerzhitsky. (E) White silicic ignimbrite with enclosing thick gray mafic ignimbrite in the Unkanovich River valley, 9 km north of the lake. Photo by Nikolai Smelov. (F) Distal KO ash at Shumshu island (Northern Kurile Islands), $90 \mathrm{~km}$ southwest of the caldera. Combination of the coarse (bottom) and fine ash (top) suggests that the ash bed comprises both pumice fallout (unit II) and co-ignimbrite ash (unit III). Photo by Vera Ponomareva. 
A

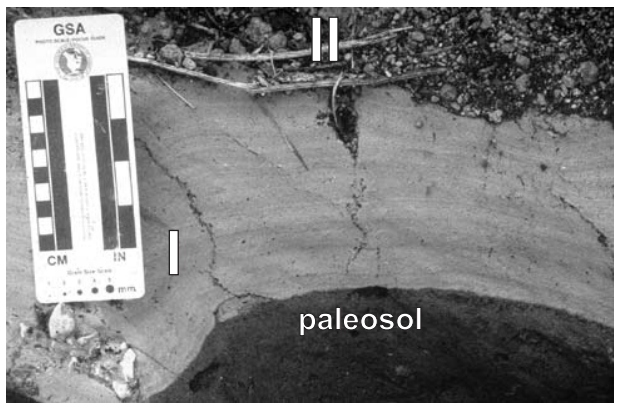

B

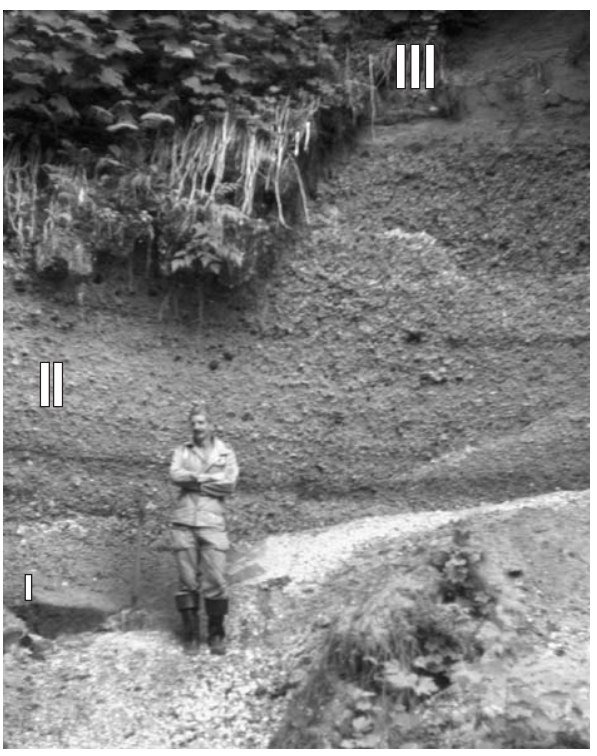

C

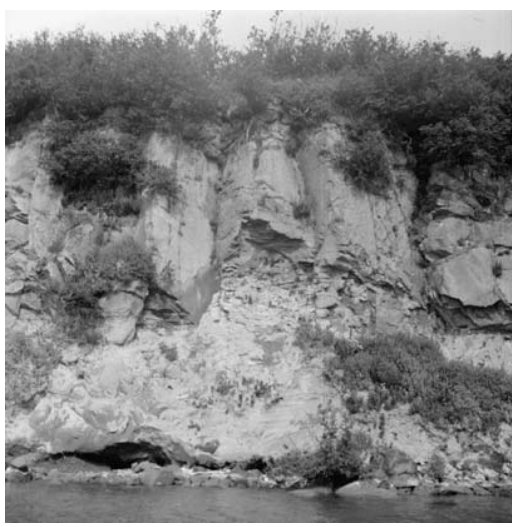

D

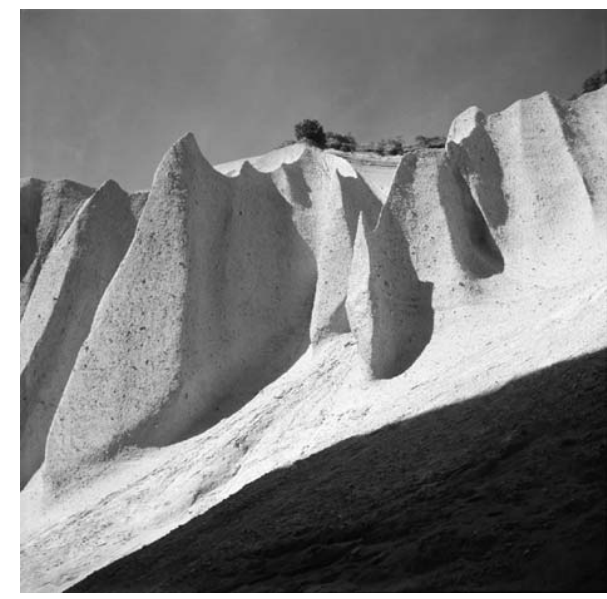

$\mathrm{E}$
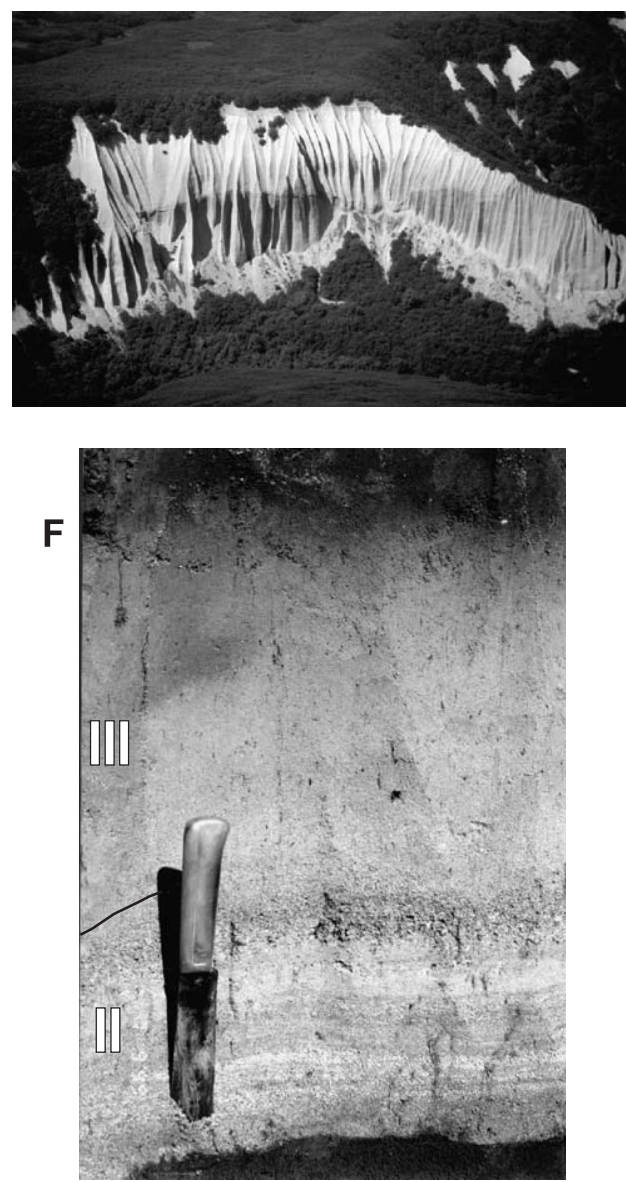
Table 1

Representative whole rock analyses of Kurile Lake caldera-forming eruption products and related rocks

\begin{tabular}{|c|c|c|c|c|c|c|c|c|c|c|c|c|c|c|c|c|c|c|}
\hline \multirow[t]{3}{*}{ Unit } & \multirow{3}{*}{$\begin{array}{l}\text { Pre-KO } \\
\text { fall unit } \\
1\end{array}$} & \multirow{3}{*}{$\begin{array}{l}\text { Black } \\
\text { scoria } \\
2\end{array}$} & \multicolumn{8}{|c|}{ Proximal KO products } & \multicolumn{2}{|c|}{ Distal KO ash } & \multirow{3}{*}{$\begin{array}{l}\begin{array}{l}\text { Extrusive } \\
\text { dome }\end{array} \\
13\end{array}$} & \multicolumn{5}{|c|}{ Iliinsky volcano products } \\
\hline & & & \multirow{2}{*}{$\frac{\mathrm{I}}{3}$} & \multirow{2}{*}{$\frac{\mathrm{II}}{4}$} & \multirow{2}{*}{$\frac{\mathrm{II}}{5}$} & \multirow{2}{*}{$\frac{\mathrm{III}}{6}$} & \multirow{2}{*}{$\frac{\mathrm{III}}{7}$} & \multirow{2}{*}{$\frac{\mathrm{III}}{8}$} & \multirow{2}{*}{$\frac{\text { III }}{9}$} & \multirow{2}{*}{$\frac{\mathrm{III}}{10}$} & \multirow{2}{*}{$\frac{\text { Coarse }}{11}$} & \multirow{2}{*}{$\frac{\text { Very fine }}{12}$} & & \multirow{2}{*}{$\frac{\text { Lava }}{14}$} & \multirow{2}{*}{$\frac{\text { Fall }}{15}$} & \multirow{2}{*}{$\frac{\text { Lava }}{16}$} & \multirow{2}{*}{$\frac{\text { Fall }}{17}$} & \multirow{2}{*}{$\frac{\text { Lava }}{18}$} \\
\hline & & & & & & & & & & & & & & & & & & \\
\hline $\mathrm{SiO}_{2}$ & 63.35 & 50.94 & 64.62 & 70.19 & 68.46 & 71.46 & 64.81 & 60.01 & 55.05 & 51.95 & 65.10 & 70.74 & 64.25 & 51.84 & 52.34 & 59.50 & 62.42 & 64.38 \\
\hline $\mathrm{TiO}_{2}$ & 1.00 & 1.07 & 0.50 & 0.27 & 0.28 & 0.29 & 0.52 & 0.71 & 0.71 & 0.84 & 0.58 & 0.57 & 0.63 & 0.95 & 1.12 & 0.77 & 1.02 & 0.74 \\
\hline $\mathrm{Al}_{2} \mathrm{O}_{3}$ & 15.57 & 19.21 & 15.81 & 14.56 & 15.15 & 14.02 & 16.24 & 19.86 & 19.29 & 17.99 & 15.55 & 13.27 & 15.60 & 19.37 & 17.56 & 19.06 & 16.14 & 16.75 \\
\hline $\mathrm{Fe}_{2} \mathrm{O}_{3}$ & 2.37 & 5.64 & 4.18 & 1.91 & 1.91 & 1.91 & 4.38 & 5.21 & 7.36 & 9.84 & 2.52 & 1.44 & 4.31 & 6.94 & 5.62 & 4.03 & 2.35 & 3.36 \\
\hline $\mathrm{FeO}$ & 1.67 & 2.85 & & & & & & & & & 0.40 & 0.41 & 2.02 & 1.77 & 3.23 & 1.57 & 2.29 & 2.03 \\
\hline $\mathrm{MnO}$ & 0.11 & 0.16 & 0.12 & 0.07 & 0.07 & 0.07 & 0.11 & 0.13 & 0.15 & 0.18 & 0.15 & 0.08 & 0.31 & 0.16 & 0.19 & 0.62 & 0.12 & 0.01 \\
\hline $\mathrm{MgO}$ & 0.69 & 4.60 & 1.45 & 0.36 & 0.35 & 0.39 & 1.57 & 1.72 & 3.50 & 5.02 & 1.46 & 0.66 & 2.00 & 4.66 & 6.11 & 2.08 & 1.37 & 1.72 \\
\hline $\mathrm{CaO}$ & 4.96 & 11.39 & 4.02 & 2.26 & 2.47 & 2.42 & 4.45 & 6.89 & 8.85 & 9.88 & 3.76 & 1.06 & 4.50 & 9.90 & 9.49 & 6.64 & 5.20 & 5.02 \\
\hline $\mathrm{Na}_{2} \mathrm{O}$ & 4.71 & 2.35 & 3.85 & 4.37 & 4.36 & 4.51 & 3.94 & 4.51 & 3.29 & 2.52 & 3.80 & 4.38 & 4.30 & 2.61 & 2.95 & 3.64 & 4.45 & 4.26 \\
\hline $\mathrm{K}_{2} \mathrm{O}$ & 1.54 & 0.27 & 1.51 & 1.79 & 1.68 & 1.92 & 1.45 & 0.76 & 0.58 & 0.45 & 1.43 & 2.19 & 1.30 & 0.56 & 0.70 & 1.25 & 1.41 & 1.56 \\
\hline $\mathrm{P}_{2} \mathrm{O}_{5}$ & 0.03 & 0.11 & 0.11 & 0.04 & 0.04 & 0.05 & 0.11 & 0.20 & 0.13 & 0.11 & 0.14 & 0.12 & 0.16 & 0.22 & 0.15 & 0.21 & 0.17 & 0.14 \\
\hline LOI & 3.66 & 0.93 & 3.06 & 4.19 & 4.48 & 2.85 & 2.55 & 0.49 & 0.57 & 0.16 & 5.21 & 4.66 & 0.16 & 0.67 & 0.44 & 1.57 & 3.30 & 0.16 \\
\hline Total & 99.66 & 99.52 & 99.23 & 100.01 & 99.25 & 99.89 & 100.13 & 100.49 & 99.48 & 98.94 & 100.10 & 99.58 & 99.54 & 99.65 & 99.90 & 100.94 & 100.24 & 100.13 \\
\hline $\mathrm{S}$ & & & 101 & 80 & 68 & 75 & 100 & 50 & 177 & 288 & & & & & & & & \\
\hline $\mathrm{Sc}$ & & & 13.63 & 8.08 & 9.83 & 8.41 & 13.64 & 15.98 & 25.41 & 38.40 & & 8.28 & 14.88 & 36.80 & 32.20 & 21.96 & 15.13 & 20.58 \\
\hline V & & & 59 & 10 & 14 & 17 & 53 & 80 & 193 & 326 & & & & & & & & \\
\hline $\mathrm{Cr}$ & & & 9.2 & & & 8 & & 6 & 27 & 56 & & 5 & 6 & 58 & 131 & 15 & 11 & 10 \\
\hline $\mathrm{Ni}$ & & & 6 & 3 & 3 & 5 & 5 & 3 & 11 & 12 & & & & & & & & \\
\hline $\mathrm{Cu}$ & & & 19 & 11 & 9 & 27 & 27 & 13 & 28 & 54 & & & & & & & & \\
\hline $\mathrm{Zn}$ & & & 50 & 36 & 37 & 39 & 46 & 52 & 63 & 70 & & 35 & 56 & 74 & 78 & 78 & 61 & 74 \\
\hline $\mathrm{Ga}$ & & & 15 & 13 & 14 & 14 & 15 & 19 & 18 & 17 & & & & & & & & \\
\hline As & & & 8 & 9.4 & 11.0 & 11.9 & 7.8 & 4.7 & 4.1 & 3.9 & & 10.5 & 2.3 & 2.0 & 2.6 & 5.2 & 6.9 & 5.4 \\
\hline $\mathrm{Br}$ & & & 0.83 & 0.59 & 4.50 & 1.14 & 2.10 & 0.30 & & & & 2.29 & & 0.49 & & 0.73 & 1.89 & 2.06 \\
\hline $\mathrm{Rb}$ & & & 26 & 30 & 29 & 31 & 26 & 12 & 9 & 7 & & 37 & 21 & & 8 & 23 & 26 & 19 \\
\hline $\mathrm{Sr}$ & & & 235 & 159 & 175 & 172 & 258 & 393 & 349 & 300 & & & 240 & 331 & 256 & 290 & & 256 \\
\hline
\end{tabular}




\begin{tabular}{|c|c|c|c|c|c|c|c|c|c|c|c|c|c|c|c|}
\hline $\mathrm{Y}$ & 25 & 31 & 32 & 34 & 23 & 21 & 19 & 18 & & & & & & & \\
\hline $\mathrm{Zr}$ & 128 & 182 & 180 & 172 & 127 & 74 & 58 & 49 & & & & & & & \\
\hline $\mathrm{Nb}$ & 3 & & 1 & 3 & 2 & 2 & 2 & & & & & & & & \\
\hline Mo & 3 & 2 & 2 & 3 & 2 & 1 & 1 & 1 & & & & & & & \\
\hline $\mathrm{Sb}$ & 0.45 & 0.48 & 0.48 & 0.42 & 0.47 & 0.22 & 0.23 & 0.17 & 0.34 & 0.1 & & 0.15 & 0.32 & 0.33 & 0.40 \\
\hline Cs & 1.61 & 1.99 & & 2.11 & 1.69 & 0.76 & 0.63 & 0.42 & 2.29 & 0.85 & 0.51 & 0.63 & 1.13 & 1.37 & 1.45 \\
\hline $\mathrm{Ba}$ & 365 & 402 & 376 & 423 & 395 & 240 & 178 & 137 & 455 & 301 & 97 & 156 & 268 & 294 & 320 \\
\hline $\mathrm{La}$ & 10.37 & 10.26 & 9.74 & 10.64 & 8.42 & 5.95 & 4.31 & 3.37 & 10.94 & 9.20 & 3.15 & 6.67 & 7.21 & 9.04 & 8.45 \\
\hline $\mathrm{Ce}$ & 24.2 & 25.2 & 23.5 & 24.9 & 19.9 & 14.2 & 11.6 & 8.4 & 26.9 & 21.0 & 8.9 & 17.4 & 17.8 & 21.1 & 21.5 \\
\hline $\mathrm{Nd}$ & 11.4 & 11.2 & 14.2 & 15.0 & 9.0 & 7.2 & 5.9 & 5.5 & 14.7 & 12.3 & 5.1 & 7.5 & 10.6 & 10.7 & 11.5 \\
\hline $\mathrm{Eu}$ & 0.97 & 0.93 & 1.00 & 0.94 & 0.85 & 1.13 & 0.88 & 0.71 & 0.90 & 0.98 & 0.79 & 0.91 & 1.06 & 1.00 & 1.14 \\
\hline $\mathrm{Tb}$ & 0.62 & 0.67 & 0.72 & 0.72 & 0.53 & 0.50 & 0.47 & 0.38 & 0.77 & 0.66 & 0.49 & 0.49 & 0.67 & 0.62 & 0.77 \\
\hline $\mathrm{Yb}$ & 2.53 & 3.56 & 3.47 & 3.65 & 2.43 & 1.95 & 1.79 & 1.73 & 3.92 & 2.91 & 1.91 & 1.98 & 2.78 & 2.71 & 3.33 \\
\hline $\mathrm{Lu}$ & 0.36 & 0.58 & 0.56 & 0.54 & 0.37 & 0.27 & 0.25 & 0.24 & 0.59 & 0.44 & 0.26 & 0.24 & 0.43 & 0.41 & 0.48 \\
\hline $\mathrm{Hf}$ & 3.69 & 5.40 & 5.13 & 4.98 & 3.48 & 2.19 & 1.82 & 1.55 & 5.24 & 3.65 & 1.45 & 2.20 & 3.09 & 3.51 & 3.65 \\
\hline $\mathrm{Ta}$ & 0.16 & 0.30 & 0.28 & 0.17 & 0.15 & 0.17 & 0.11 & 0.25 & 0.21 & 0.15 & & 0.12 & 0.16 & 0.15 & 0.17 \\
\hline $\mathrm{Pb}$ & 7 & 10 & 10 & 9 & 7 & 6 & 4 & 6 & & & & & & & \\
\hline Th & 2.00 & 2.21 & 2.26 & 2.16 & 2.08 & 0.75 & 0.58 & 0.51 & 2.43 & 1.54 & 0.42 & 0.71 & 1.34 & 1.75 & 1.51 \\
\hline
\end{tabular}

Major element analyses 1, 2, 11-13 were obtained by "wet" chemical analysis in Geological Institute $(1,2)$ and Institute of Volcanology (11-13), Russia. Other major element and all trace element analyses were made by XRF and INAA in New Mexico Institute of Mining and Technology, USA. All analyses of proximal pyroclastic deposits were performed on large single pumice or scoria clasts. Roman numerals indicate main units of the KO pyroclastic sequence (I—initial phreatomagmatic, II-plinian fallout, III—ignimbrite). Blank space for $\mathrm{FeO}$ indicates that total $\mathrm{Fe}$ is given as $\mathrm{Fe}_{2} \mathrm{O}_{3}$; blank space for other elements means that the contents has not been determined. In the text we refer to contents of $\mathrm{SiO}_{2}$ in analyses, recalculated to 100\%, LOI free. Samples: 1-pre-KO tephra, 9-10 ka BP (sample 1388/1); 2-black scoria between KO units I and II (1380/2). Proximal KO eruption products: 3-ignimbrite of the initial stage of the eruption, east of Kurile Lake (96KAM21); 4 -plinian fallout, Pauzhetka village (97KAM17BS); 5-plinian fallout, Pauzhetka village (97KAM17A); 6-ignimbrite, Inkaniush River (96KAM9); 7—ignimbrite, foot of Iliinsky volcano (96KAM18); 8-ignimbrite, Iliinskaya River basin (96KAM3); 9ignimbrite, Inkaniush River (96KAM12); 10 -ignimbrite, Snezhnyi River (97KAM29DB). Distal KO ash: 11 - coarse ash enriched in crystal grains, 180 km NNW of the caldera, town of Ust'-Bolsheretsk (45-1-74); 12 - distal KO very fine vitric ash, Magadan region, $\sim 1000 \mathrm{~km}$ NW of the source (MAG-1). Post-caldera erupted products: 13-intracaldera extrusive dome Serdze Alaida (86680). Iliinsky volcano:14 - lava flow, SW slope (86615); 15 — black scoria from mixed tephra layer (1327/3c); 16 - lava flow, SW slope (86621); 17—light pumice from mixed tephra layer (1327/3a); 18 -lava flow, W slope, flank vent (86650). 
(Ponomareva et al., 2001). The Early Holocene paleosol contains a few tephra layers from distant volcanoes, but only one from the Kurile Lake area. This 2-cmthick tephra layer is light-gray fine ash with $1-2-\mathrm{cm}$ diameter dacite pumice lapilli compositionally similar to the dacite pumice from the younger Kurile Lake caldera-forming eruption (Table 1, an. 1). The tephra is best identified in sections immediately north of the Kurile Lake, and probably resulted from a small eruption in the depression pre-dating the Holocene caldera. In sections the tephra occurs between Late Pleistocene moraine deposits and the $\sim 8800{ }^{14} \mathrm{C}$ years $\mathrm{BP} \mathrm{KS}_{4}$ marker tephra from Ksudach (Braitseva et al., 1997b). Thus, the age of the tephra is estimated at 9-10 ka, and it is the only Holocene precursor to the Kurile Lake caldera-forming eruption.

\section{The Kurile Lake caldera-forming eruption proximal deposits}

An idealized section of the eruptive sequence is presented in Fig. 4 and selected individual sections of the caldera deposits and their locations are presented in Figs. 5 and 6. The eruption sequence comprises three main units: (I) phreatoplinian deposits of an initial phase; (II) plinian pumice and ash fall deposits; and (III) voluminous ignimbrite and accompanying surge beds and co-ignimbrite fallout (Fig. 4). No depositional breaks are observed within the pyroclastic sequence indicating that the eruption and emplacement of the deposits were continuous. The ignimbrite has a distinctive lithologic and geochemical zonation.

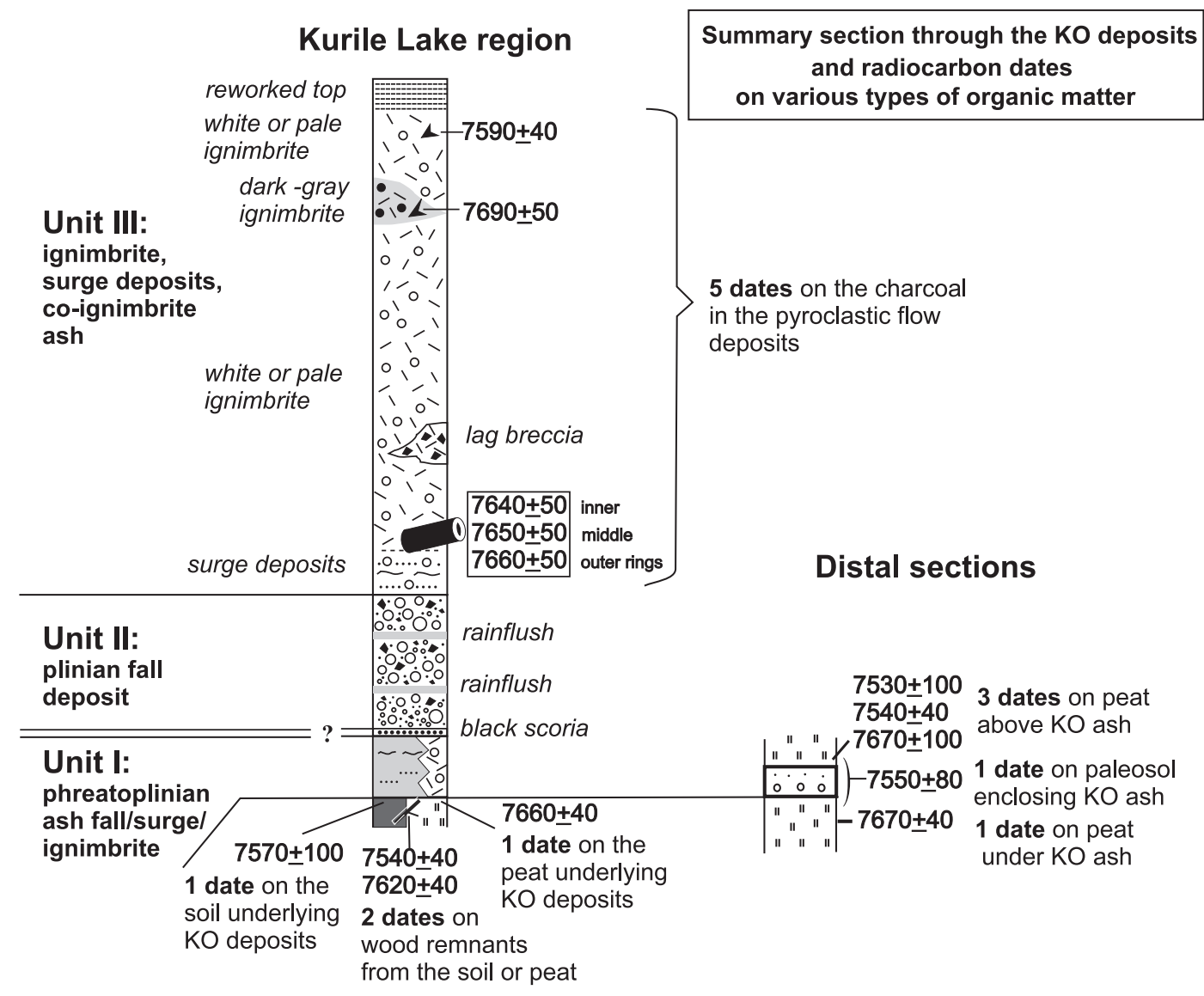

Fig. 4. Summary section through the Kurile Lake caldera-forming eruption deposits and 14 radiocarbon dates used to calculate the eruption age. See Fig. 5 for explanation of shade patterns. 


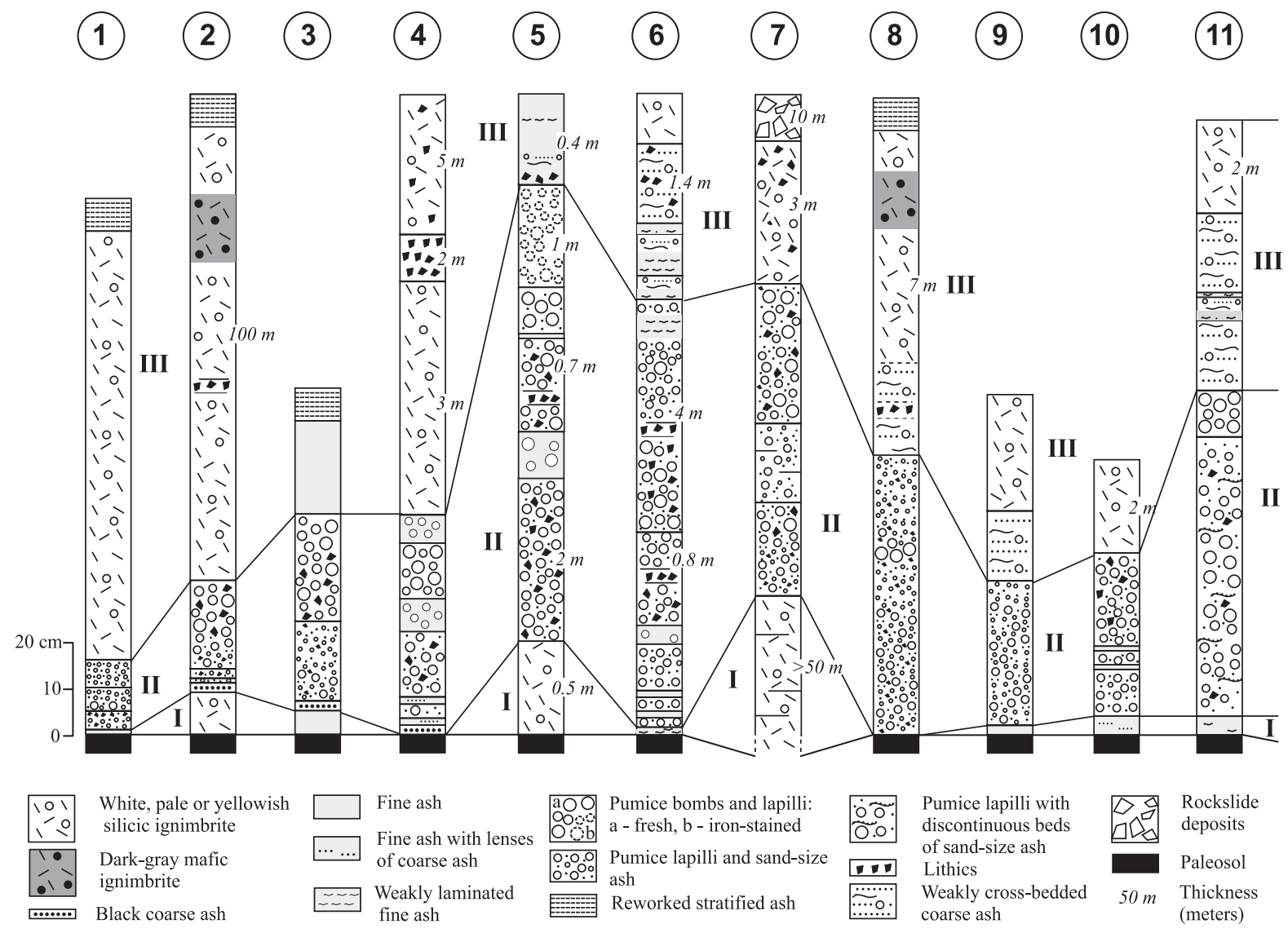

Fig. 5. Schematic sections through the KO deposits. The locations of the sections are shown in Fig. 6. I, II, and III are the main eruptive units for the deposits. See scale (on left) for thickness of units, unless otherwise indicated.

\subsection{Unit I: pyroclastic deposits of the initial phase}

Unit I of the KO eruption sequence rests on a paleosol and is in sharp contact with the overlying unit II pumice-rich fall deposit. In most outcrops (Fig. 5, Sections 1, 3, 9-11), unit I consists of well-sorted pale very fine vitric ash in places containing thin lenses of coarser ash and showing weak lamination (Figs. 2 and $3 \mathrm{~A}$ ). The ash is interpreted as a phreatoplinian fall deposit based on its fine grain size, widespread distribution and terrain-draping character (Sparks and Walker, 1977; Self and Sparks, 1978; Self, 1983). A phreatoplinian origin for this basal unit is probable since the pre-Holocene depression, an obvious locus of the initial eruption, is likely to have contained a lake.

Immediately east of the lake the initial phase of the eruption is represented by a $>50-\mathrm{m}$ thick, multi-flow unit, light-yellow ignimbrite (Fig. 5, Section 7). It is composed predominantly of rhyolitic pumice (Table 1, an. 3) and contains a high content of fine-grained lithics. This basal ignimbrite fills gullies facing the lake and forms a terrace that drops steeply towards the lake. The base of the $\mathrm{KO}$ deposits is not exposed here, and the top of the ignimbrite is $\sim 250 \mathrm{~m}$ a.s.l.

On the slopes of the deep Vychenkiya River valley immediately north of the lake at approximately the same altitude, the basal unit consists of a 40-50-cmthick ignimbrite (Fig. 5, Section 5). Nine kilometers farther north in the Unkanovich River valley (Fig. 5, Section 2) the basal ignimbrite is only $10 \mathrm{~cm}$ thick. To get to the Unkanovich River valley, the pyroclastic density current had to overrun a 250 -m-high divide between the Vychenkiya and Unkanovich river valleys (Fig. 2). In the other radial valleys in the 
vicinity of the lake, the base of the eruptive sequence is not exposed, so the true extent of the initial ignimbrite is not known. In a section west of the lake, the basal unit is a thin, coarse to fine ash sometimes showing a weak cross-bedding unit that is interpreted as a surge deposit (Fig. 5, Section 6).

All these facies underlying the plinian fall deposit stratigraphically replace each other and have never been observed in the same section. Very likely all of them correspond to the same initial phreatoplinian phase of the eruption (Fig. 4).

\subsection{Unit II: plinian pumice-fall deposit}

Proximal tephra-fall deposits are dominated by lapilli and bombs of white or light-gray pumice of rhyolite and dacite composition (Fig. 3B; Table 1). Most outcrops have 2-5 pumice fall layers separated by gray fine ash interpreted as rainflush tephra (Fig. 5, Sections 4-6, 10). At some localities three pumice layers can be identified, differing from each other in grain-size but not separated by any other beds (Fig. 5, Sections $1-3,7,11)$. In some sections, however, only one pumice-fall layer can be identified (Fig. 5, Sections 8 and 9). The general pattern of pumice fall dispersal is to the northwest with a well-defined axis (Fig. 8). The lack of distinct continuous boundaries between individual pumice-fall layers suggests that this phase of the eruption was rather short-lived. Pumice bombs and lapilli reach $20 \mathrm{~cm}$ diameter on the northern shore of the lake, and $5 \mathrm{~cm}$ in a site 50 $\mathrm{km}$ north of the source (Fig. 6). Some pumice layers are enriched in lithic clasts (Fig. 5); in some proximal outcrops, however, the latter form individual layers (Fig. 5, Sections 5 and 6).

In several sections north of the lake, the pumicefall unit is underlain by a $1-2 \mathrm{~cm}$ thick layer of sandsize low-potassic basaltic scoria (Fig. 5, Sections 24); it lies between units I and II, or right on the paleosol when unit $\mathrm{I}$ is missing from the section (Fig. 5). The origin of this basaltic ash is enigmatic, but it differs from basaltic andesite compositions found in the $\mathrm{KO}$ eruptive products (Table 1, an. 2).

\subsection{Unit III: KO ignimbrite}

The KO ignimbrite is more than $150 \mathrm{~m}$ thick near Kurile Lake and extends over $50 \mathrm{~km}$ from source. The ignimbrite has a distinctive valley-ponding facies and a thin veneer facies on ridges and higher plateau, both which are similar to the Taupo ignimbrite (Wilson, 1985) (Fig. 6). The pyroclastic flows which deposited the ignimbrite entered the Pacific Ocean to the east and the Sea of Okhotsk west of Kurile Lake. The ignimbrite is poorly sorted, containing ash and lapilli to block sized pumice and scoriaceous pumice as well as lithic fragments, accretionary lapilli, pumice concentration zones, fossil fumaroles and carbonized wood. Normally the ignimbrite is structureless and forms a single unit lacking bedding with the exception of outcrops close to the river junctions where different branches of pyroclastic flows that came down individual valleys overlapped, and thus mimic a suite of flow units. Most of the unit is a white, pale or lightgray pumice lapilli tuff dominated by rhyolitic pumice clasts (Fig. 3D; Table 1, an. 5). This is the only type of ignimbrite observed west of Kurile Lake and in distal outcrops.

Proximal deposits of the ignimbrite in valleys north, east and south of Kurile Lake grade from a white rhyolitic lapilli tuff upwards into dark-gray or black lapilli tuff and back into white dominantly rhyolitic lapilli tuff (Fig. 3E, and 5, Sections 2 and 8; Table 1). In the darker mafic zones the clasts are black scoriaceous basaltic-andesite and andesite, and a variety of black-and-white banded (co-mingled) scoria. The transitions from rhyolitic to basaltic andesite and then back to rhyolite are gradational. The darkgray mafic ignimbrite is restricted to the valleyponded facies and is absent on the ridges and plateaus. In places the mafic ignimbrite is more than $15-20 \mathrm{~m}$ thick. Proximal dark-gray ignimbrite is lithified and individual clasts are commonly slightly flattened indicating some compression and incipient welding. Farther downflow, a distinct dark-gray band in the outcrops transforms into huge gray lenses of mafic material continuously grading into the enclosing white silicic tuff. This gray lens structure finally fades away at a distance of about $15 \mathrm{~km}$ from the lake. Zoned ignimbrites grading from silicic at the base to mafic at the top are common and have been well documented at Crater Lake (Bacon, 1983) and in the Aniakchak ignimbrites (Miller et al., 1998). Such zonation is thought to reflect density stratification in the magma chamber (Cas and Wright, 1987). However, the presence of rhyolite ignimbrite overlying a mafic zone 


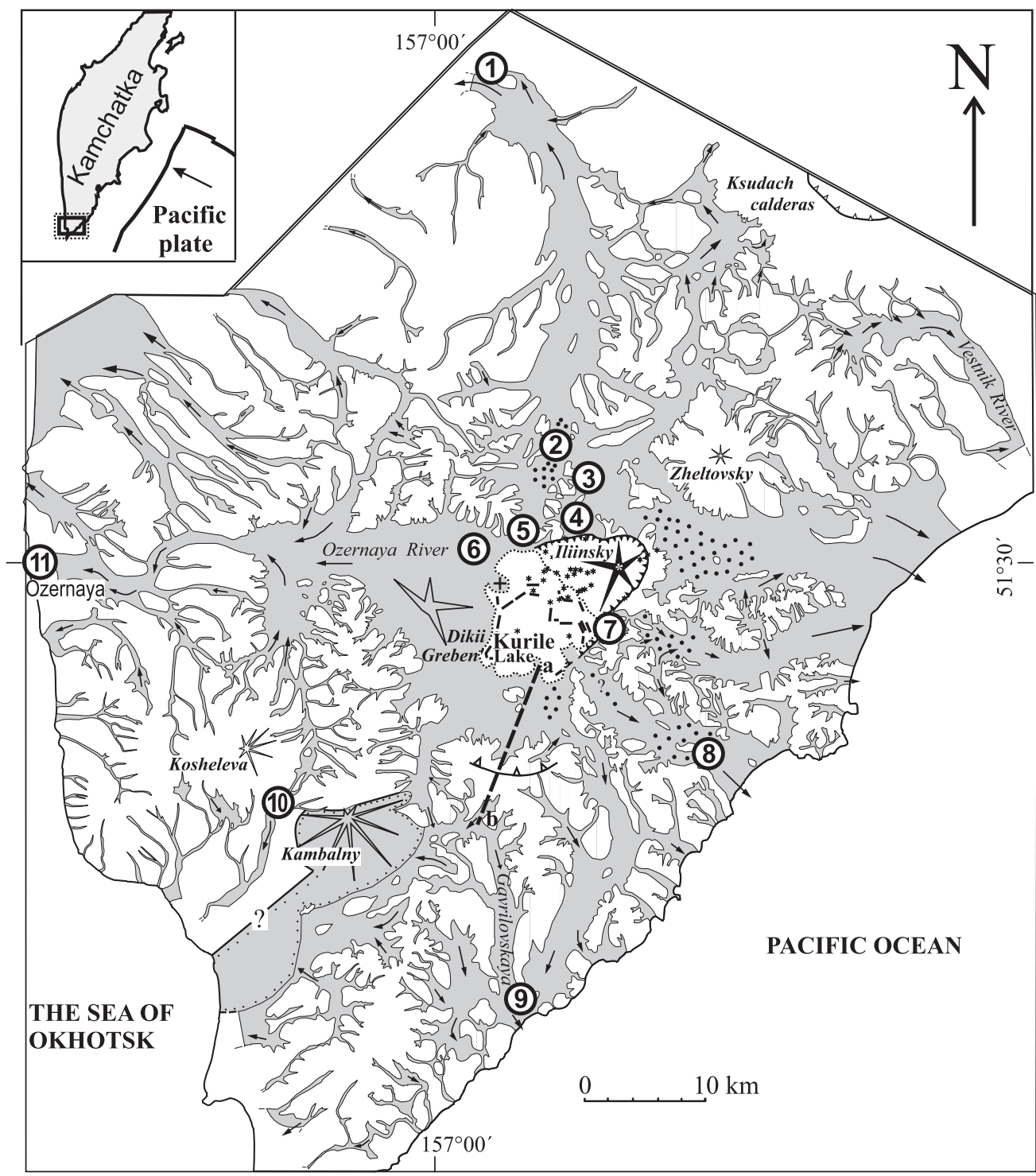

\section{Kurile Lake caldera}

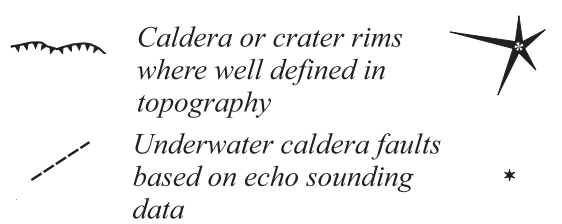

\section{Intra-caldera vents}

Iliinsky volcano

Monogenetic craters and extrusive domes
*

Other post-caldera volcanoes

Border of the Kambalny deposits $\ldots$ overlying the KO ignimbrite

(9) Sections shown in Fig.5

Fig. 6. Distribution of the KO ignimbrite outflow sheet (shaded and with arrows showing flow directions). Black dots within the ignimbrite show the locations of enclosed dark-gray mafic ignimbrite. The circled numbers show the locations of sections in Fig. 5. The welded ignimbrite at Pulomynk Peninsula is indicated by a cross (below and to the right of Section 6). Dashed line $a-b$ south of the lake marks the profile shown in Fig. 7. See Fig. 2 for explanation of other symbols. 
distinguishes the $\mathrm{KO}$ ignimbrite from the more conventional silicic to mafic sequences and requires special explanation involving chamber geometry and venting characteristics (Rinkleff, 1999).

A welded variety of the proximal silicic ignimbrite crops out on the Pulomynk Peninsula west of Kurile Lake (Figs. 3C and 6). The lower contact is not exposed and the top is overlain by lacustrine deposits, so the exact position and extent of the welded portion in the overall pyroclastic succession is not clear.

Ignimbrite exposed north of the lake contains distinctive pockets of lag breccia (Druitt and Sparks, 1981). The breccias are clast-supported with varying amounts of ignimbrite matrix and always occur below the dark-gray ignimbrite. The appearance of the breccias may mark a transition to a ring-fracture stage of the climactic eruption (Bacon, 1983) or to widening of a central vent.

Accretionary lapilli are a common constituent of the ignimbrite showing that lake or meteoric water was an important component during the eruption (Self, 1983; Wilson, 1985). Ignimbrite exposed near the Pacific Ocean is extensively reworked and finespoor, possibly due to secondary explosions resulting from seawater-pyroclastic flow interaction. Charcoal $\operatorname{logs}$ up to $20 \mathrm{~cm}$ in diameter and charred twigs are common in the ignimbrite. They occur throughout the thick ignimbrite exposures and also in the thin distal extremities of the ignimbrite $50 \mathrm{~km}$ from source.
The pyroclastic density current which deposited the KO ignimbrite was likely to have high mobility similar to that which deposited the Taupo ignimbrite (Wilson, 1985). This is demonstrated by occurrences of KO ignimbrite SSW of Kurile Lake behind major topographic barriers. These include a 900-1000-mhigh scarp formed by the Pleistocene Pauzhetka caldera (Figs. 6 and 7, Gavrilovskaya valley), the slopes of Zheltovsky volcano, and ridges $\sim 40 \mathrm{~km}$ away from the source northeast of Zheltovsky (Fig. 6, Vestnik valley). However, the mobility of the KO pyroclastic density currents should be studied in more detail as they followed an intricate network of river valleys and their travel was likely to be quite complex. Locally, the ignimbrite is either capped or stratigraphically replaced by a fine pale co-ignimbrite fall ash (Fig. 5, Sections 3 and 5). Along the upper headwaters of the Ozernaya River, the thick KO ignimbrite was disrupted and displaced during extrusion of Dikii Greben' domes, so that the top of the KO sequence on the southern bank of the river is now about $70 \mathrm{~m}$ higher than on the northern bank.

Many outcrops, especially on the surrounding hills and plateaus (Section 5), show various cross-bedded pyroclastic units which either underlie ignimbrite (Fig. 5, Sections 6, 8, 9, 11) or stratigraphically replace it. Some of these beds probably represent localized areas of turbulence in the pyroclastic density current and traditionally would be called surge deposits. The cross bedded units are discontinuous and cannot be correlated between outcrops.

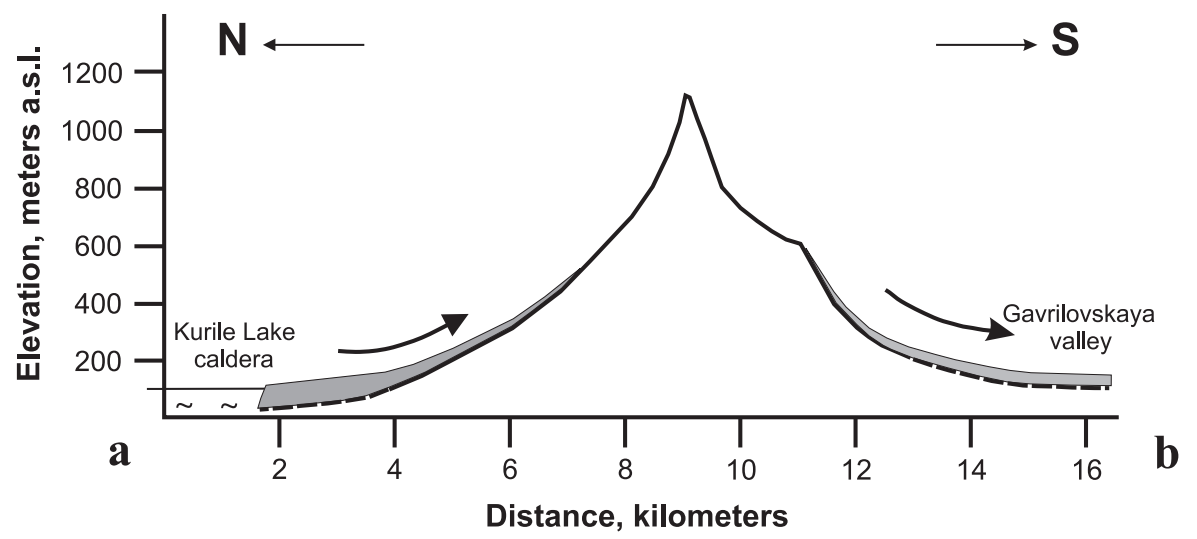

Fig. 7. Schematic profile showing distribution of the KO ignimbrite south of the Kurile Lake, along line a-b in Figs. 2 and 6 . The pyroclastic flow surmounted a 1000-m-high scarp of the Mid-Pleistocene Pauzhetka caldera and flowed down the Gavrilovskaya River valley towards the Pacific Ocean. 
In many places, the KO pyroclastic succession is topped with avalanche and debris flow deposits, which probably formed during caldera collapse. Individual debris avalanche deposits are easily identified on airphotos and in the field. One of the largest landslides formed Glinyany ("Clay") Peninsula on the SE shore of Kurile Lake.

The upper parts of the valley-ponded and veneer ignimbrites are commonly reworked with laminated pumiceous and crystal-rich layers of varying grainsize (Fig. 5, Sections 1-3, 8). The post-ignimbrite soil-and-pyroclastic cover near the lake is several meters thick and contains more than 50 individual tephra beds of various color, grain-size and composition from both local and distant volcanoes (Ponomareva et al., 2001).

The deposition of all KO units was strongly influenced by the irregular topography of the area. Pumice clasts of the Plinian fall unit sometimes moved downslope during deposition. The pyroclastic density currents followed many different valleys and overlapped at their junctions. These processes resulted in the local deposition of a more variable pyroclastic sequence than that generated by the eruption itself, and these must be considered when interpreting the eruptive sequence.

\section{Distal ash-deposits of the Kurile Lake caldera-forming eruption (KO)}

$\mathrm{KO}$ tephra is an important regional Holocene marker horizon as it can be traced over the southern Kamchatka Peninsula (Fig. 8) and beyond to mainland Asia. In Kamchatka, the KO has been traced north to Karymsky, Maly and Bolshoi Semiachik volcanoes, where it overlies the $7900{ }^{14} \mathrm{C}$ years BP Karymsky caldera deposits (Braitseva et al., 1997b). KO ash was dispersed to the northwest of the caldera across the Sea of Okhotsk, where it has been identified in sediment cores (Gorbarenko et al., 2000, 2002), and on mainland Asia, from the Magadan region to the upper streams of the Indigirka River, about $1700 \mathrm{~km}$ NW of the source (Fig. 8, inset) (Melekestsev et al., 1991; Anderson et al., 1998). The KO is 5-7 cm thick in outcrops near Magadan, $3 \mathrm{~cm}$ thick near Elikchan Lake, 180-200 km NNW of Magadan (Melekestsev et al., 1991), and $0.1 \mathrm{~cm}$ thick in lake sediments in the upper reaches of the Indigirka River (Fig. 8, inset) (Anderson et al., 1998). The identification of the KO ash in the Magadan region and Elikchan lakes is confirmed using microprobe analyses of glass and chemical analysis of bulk samples (Tables 1 and 2).

$\mathrm{KO}$ ash has also been recognized in the northern Kurile Islands (Braitseva et al., 1995; Melekestsev et al., 1994). In many sections on the northern Kurile Islands and along the western coast of Kamchatka, the ash is $10-30 \mathrm{~cm}$ thick and normally graded, with coarse ash at the bottom and fine vitric ash at the top. This sequence, and the large volume of the Kurile Lake ignimbrite (unit III), suggest that the distal tephra consists of both plinian fall and co-ignimbrite ash (Sparks and Walker, 1977; Sigurdsson and Carey, 1989) with a similar dispersal axis. On the plateau about $8 \mathrm{~km}$ north of the lake, co-ignimbrite ash constitutes about $30 \%$ of the total fallout (Fig. 5, Section 3), and $180 \mathrm{~km} \mathrm{NNW}$ of the caldera, in the Ust'-Bol'sheretsk region, where the $10-\mathrm{cm}$ isopach crosses the Sea of Okhotsk shoreline (Fig. 8), coignimbrite ash comprises about $50 \%$ of the total tephra thickness (compare with $80 \%$ at the same distance for 1815 Tambora eruption, Sigurdsson and Carey, 1989). A similar picture is observed in the northern Kurile Islands, $90 \mathrm{~km}$ southwest of the source (Fig. 3F). This suggests that co-ignimbrite ash fall probably accounts for a large part of the distal $\mathrm{KO}$ ash and must be considered when calculating the eruption volume.

Bulk compositions of distal $\mathrm{KO}$ ash range from rhyolite (fine vitric ash) to dacite (coarse ash enriched in mineral grains) with low-to-medium $\mathrm{K}_{2} \mathrm{O}$ contents (Table 1). This places the KO ash between lowpotassic Ksudach ashes and medium-potassic Karymsky caldera ash on the $\mathrm{SiO}_{2}-\mathrm{K}_{2} \mathrm{O}$ diagram (Braitseva et al., 1997b). The distal ash is characterized by homogeneous glass composition (Table 2). Specific features helpful for identification and correlation of $\mathrm{KO}$ ash are: (1) bulk $\mathrm{SiO}_{2}$ contents $64-76 \%$ depending on changing mineral/glass proportion due to eolian segregation; (2) rhyolite glass composition with low to moderate $\mathrm{Al}_{2} \mathrm{O}_{3}$ and $\mathrm{MgO}$ contents, and moderate $\mathrm{TiO}_{2}, \mathrm{FeO}, \mathrm{CaO}$ and $\mathrm{K}_{2} \mathrm{O}$ contents; (3) $\mathrm{K}_{2} \mathrm{O}, \mathrm{Y}, \mathrm{La} / \mathrm{Y}$ contents intermediate between Ksudach and Karymsky caldera tephra; and (4) minor amount of amphibole. These criteria, along with the ${ }^{14} \mathrm{C}$ ages and stratigraphy, are sufficient to discriminate $\mathrm{KO}$ 


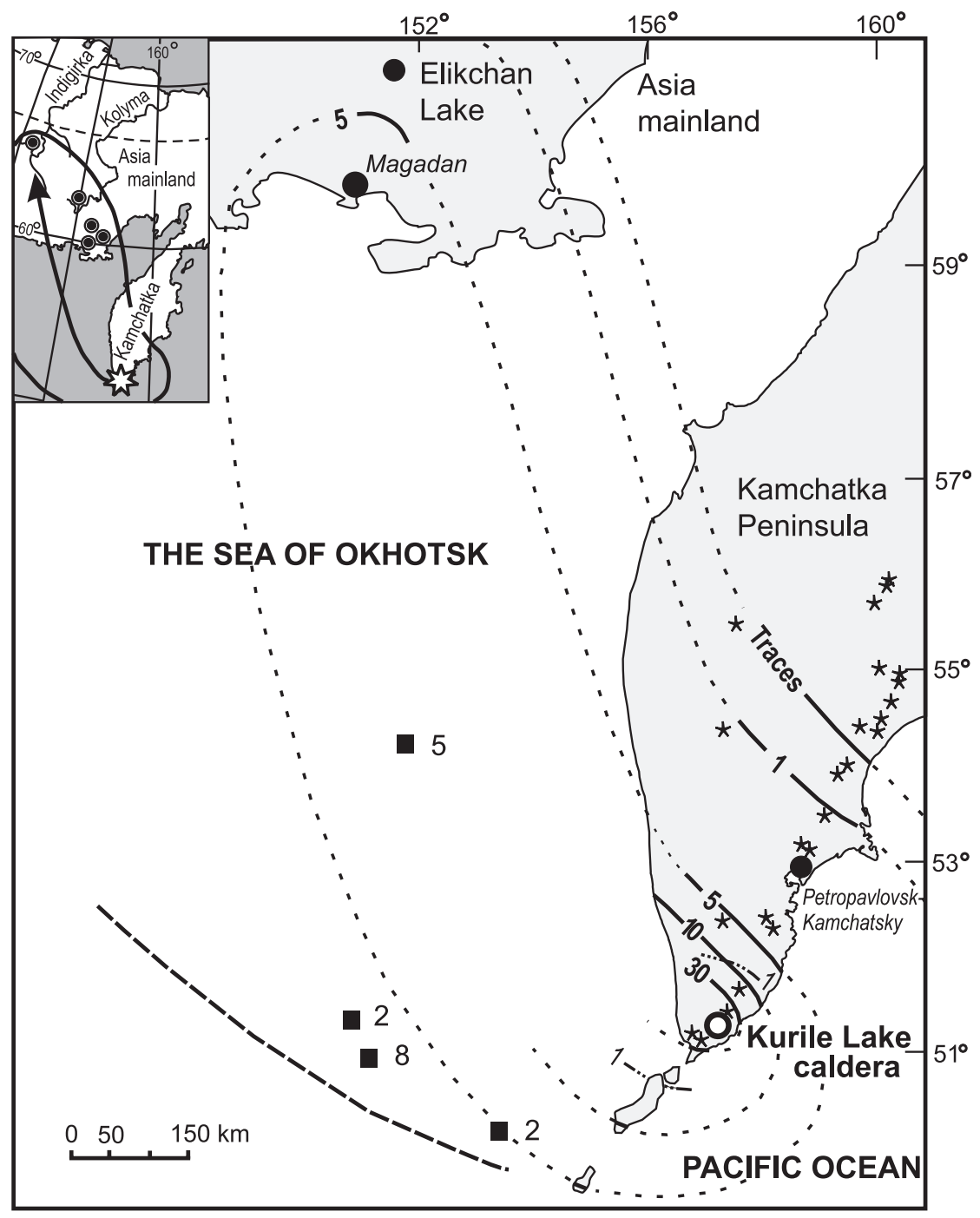

KO tephra dispersal
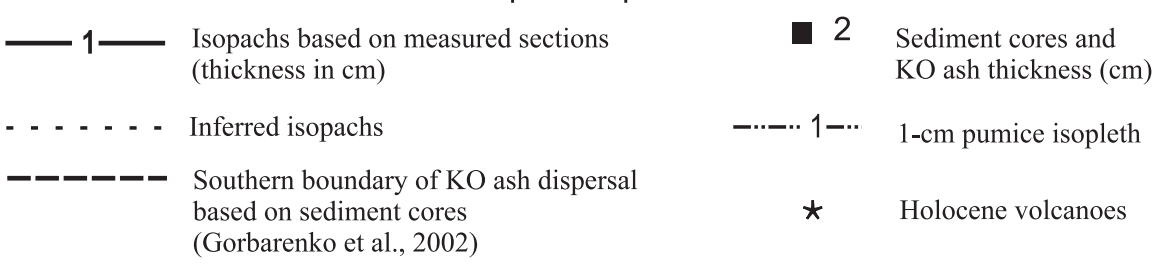

Fig. 8. Distribution of the KO fall deposits (thicknesses in $\mathrm{cm}$ ). The 30-cm isopach is for the pumice fallout (unit II) where it is overlain by KO ignimbrite (unit III). Other isopachs include fall deposits from the plinian fall unit II and co-ignimbrite ash from unit III. Inset shows sites on the Asia mainland where the KO tephra has been identified (Anderson et al., 1998) (large black dots) and inferred area of the KO fall deposits. 
Table 2

Average microprobe analyses of glass shards from KO distal tephra fall deposits

\begin{tabular}{|c|c|c|c|c|c|c|c|c|c|c|c|c|c|c|c|c|}
\hline $\begin{array}{l}\# \\
\text { Sample } \\
n \\
\end{array}$ & \multicolumn{2}{|c|}{$\begin{array}{l}1 \\
98 \text { KAM7.7 }\end{array}$} & $\begin{array}{l}2 \\
98 \mathrm{KAM} \\
10\end{array}$ & & $\begin{array}{l}3 \\
98 \mathrm{KAM} \\
8\end{array}$ & & $\begin{array}{l}4 \\
98 \mathrm{KAM} \\
5\end{array}$ & & $\begin{array}{l}5 \\
115 \mathrm{M}-9 \\
7\end{array}$ & & $\begin{array}{l}6 \\
99-27 / 1 \\
6\end{array}$ & & $\begin{array}{l}7 \\
\text { MAG-1 } \\
7\end{array}$ & & $\begin{array}{l}8 \\
\text { CKB-2 } \\
9\end{array}$ & \\
\hline $\mathrm{SiO}_{2}$ & 77.50 & \pm 0.17 & 76.76 & \pm 0.34 & 76.27 & \pm 0.26 & 77.49 & \pm 0.12 & 75.27 & \pm 0.13 & 76.68 & \pm 0.19 & 76.20 & \pm 0.35 & 76.31 & \pm 0.61 \\
\hline $\mathrm{Al}_{2} \mathrm{O}_{3}$ & 12.50 & 0.11 & 13.02 & 0.24 & 13.30 & 0.17 & 12.60 & 0.03 & 13.77 & 0.11 & 13.28 & 0.09 & 13.53 & 0.13 & 13.28 & 0.33 \\
\hline $\mathrm{FeO}^{\mathrm{a}}$ & 1.43 & 0.04 & 1.50 & 0.05 & 1.56 & 0.05 & 1.48 & 0.06 & 1.64 & 0.04 & 1.48 & 0.05 & 1.56 & 0.08 & 1.53 & 0.13 \\
\hline $\mathrm{MnO}$ & 0.05 & 0.03 & 0.07 & 0.04 & 0.04 & 0.03 & 0.06 & 0.06 & 0.06 & 0.06 & 0.08 & 0.05 & 0.05 & 0.04 & 0.07 & 0.02 \\
\hline $\mathrm{MgO}$ & 0.23 & 0.03 & 0.28 & 0.02 & 0.21 & 0.07 & 0.22 & 0.04 & 0.37 & 0.02 & 0.27 & 0.01 & 0.32 & 0.19 & 0.27 & 0.04 \\
\hline $\mathrm{Na}_{2} \mathrm{O}$ & 4.38 & 0.00 & 4.39 & 0.00 & 4.63 & 0.00 & 4.26 & 0.00 & 4.30 & 0.00 & 4.15 & 0.00 & 4.24 & 0.00 & 4.34 & 0.00 \\
\hline $\mathrm{K}_{2} \mathrm{O}$ & 2.13 & 0.03 & 2.06 & 0.07 & 2.03 & 0.06 & 2.10 & 0.08 & 2.39 & 0.08 & 2.04 & 0.06 & 2.02 & 0.03 & 2.04 & 0.09 \\
\hline $\mathrm{F}$ & 0.06 & 0.06 & 0.02 & 0.05 & 0.09 & 0.10 & 0.02 & 0.03 & 0.08 & 0.08 & 0.10 & 0.08 & 0.03 & 0.03 & 0.06 & 0.06 \\
\hline $\mathrm{Cl}$ & 0.13 & 0.02 & 0.15 & 0.01 & 0.13 & 0.02 & 0.16 & 0.01 & 0.13 & 0.01 & 0.15 & 0.03 & 0.15 & 0.01 & 0.15 & 0.02 \\
\hline $\mathrm{P}_{2} \mathrm{O}_{5}$ & 0.02 & 0.02 & 0.03 & 0.02 & 0.01 & 0.02 & 0.03 & 0.03 & 0.04 & 0.02 & 0.02 & 0.02 & 0.04 & 0.02 & 0.05 & 0.02 \\
\hline $\mathrm{SO}_{2}$ & 0.02 & 0.02 & 0.02 & 0.02 & 0.01 & 0.01 & 0.01 & 0.03 & 0.01 & 0.02 & 0.01 & 0.01 & 0.01 & 0.01 & 0.02 & 0.02 \\
\hline Total & 100.01 & & 100.00 & & 100.00 & & 100.01 & & 100.01 & & 100.01 & & 100.01 & & 99.99 & \\
\hline
\end{tabular}

Analyses were made by a Cameca SX-100 electron microprobe at New Mexico Institute of Mining and Technology. Analyses are normalized to 100\% and corrected for sodium los due to volatilization during microprobe analysis. Standard deviation of the average is shown next to each oxide.

Samples locations: 1-3: from bottom to top, three pumice fall layers (all from unit II) underlying the 1-m-thick terminal part of the KO ignimbrite, 50 km north of the caldera,

Golygina River valley; 4: $6 \mathrm{~cm}$ fall ash, probably mixture of pumice fall and co-ignimbrite ash, $130 \mathrm{~km}$ NNE of the caldera, Tolmacheva River valley; 5 : $10 \mathrm{~cm}$ fall ash, probably mixture of pumice fall and co-ignimbrite ash, $180 \mathrm{~km} \mathrm{NNW}$ of the caldera, western coast, Mitoga River mouth; 6: middle part of the normal graded ash layer (upper part of pumice fall unit II), $90 \mathrm{~km}$ southwest of caldera, Shumshu island, Northern Kurile islands (Fig. 3F); 7: 5-7 cm very fine ash, about $1000 \mathrm{~km}$ NW of the source, Magadan region, Asia mainland; 8. $3 \mathrm{~cm}$ thick very fine ash from a core from Elikchan Lake $\left(60^{\circ} 45^{\prime} \mathrm{N}, 151^{\circ} 53^{\prime} \mathrm{E}\right)$ (sample provided by Pat Anderson, Quaternary Research Center, University of Washington, and Anatolii Lozhkin, North East Research Institute, Magadan).

${ }^{\text {a }}$ Total $\mathrm{Fe}$ as $\mathrm{FeO}, n=$ number of analyses in average. 
tephra from Ksudach and Karymsky caldera ashes which were erupted about the same time (Braitseva et al., 1997b).

The KO marker ash has been used in paleovolcanological reconstructions (Braitseva et al., 1998; Melekestsev et al., 1990, 1994, 1999; Seliangin and Ponomareva, 1999), marine research (Gorbarenko et al., 2000, 2002), and environmental studies (Anderson et al., 1998). It has important tephrochronological uses as it allows correlation of various depositional successions over a large area, from Kamchatka to mainland Asia across the Sea of Okhotsk. The ash dispersal pattern suggests that the KO ash should also occur east of Kamchatka in Pacific Ocean sediments and the Northern Kurile Islands (Fig. 8).

\section{Caldera configuration and origin}

Most Holocene calderas are topographically well expressed with easily mappable rims. Examples include Crater Lake, Oregon; Karymsky, Kamchatka; and Aniakchak, Alaska (Bacon, 1983; Braitseva and Melekestsev, 1990; Miller and Smith, 1987). Kurile Lake is complicated because the exact dimensions and position of the caldera are obscured by lake water, younger sediments and/or overlapping younger volcanic deposits. Part of the western caldera rim may have been deformed during growth of the Dikii Greben' extrusive domes (Fig. 6). Rims of the midPleistocene Pauzhetka and presumable Late Pleistocene "Old" Kurile Lake calderas must be present, and may be superimposed in the lake region (Fig. 2; Melekestsev et al., 1974), which complicates the picture. Definite post-Holocene-caldera features are Iliinsky and Dikii Greben' volcanoes, and some of the extrusive domes which form islands in the lake (Fig. 6).

The Holocene caldera rim is best expressed in topography north and east of Iliinsky volcano where it cuts the pre-Iliinsky volcano and embraces Iliinsky itself (Figs. 1 and 2). This scarp can also be identified northwest and south of Iliinsky, where it cuts midPleistocene lava plateaus (Fig. 2). This well-expressed rim allowed Melekestsev et al. (1974) to confine the Holocene caldera to the edifice of pre-Iliinsky volcano only. However, the thickness of the KO pyroclastic sequence and welding of the ignimbrite, forming
Pulomynk Peninsula, suggests that the initial vent and caldera locations are under the Kurile Lake (Fig. 6). Furthermore, using bathymetric studies Zubin et al. (1982) divided Kurile Lake into northern and southern basins divided by a medial ridge $150 \mathrm{~m}$ across. The northern part is flat-bottomed with a depth of about $200 \mathrm{~m}$, whereas the southern part is $\sim 10 \mathrm{~km}$ across, roughly rectangular and characterized by short step-like segments with steep slopes of $60^{\circ}$ down to about $300 \mathrm{~m}$ depth (that is $200 \mathrm{~m}$ below present sea level). Using reconnaissance gravity and aeromagnetic surveys Zubin et al. (1982) interpreted the southern part of the lake as a Holocene caldera.

Seismic profiling by Bondarenko (1991) suggests that the northern bay of Kurile Lake is part of a preHolocene depression. The lower unit in this part of the lake is presumably a Late Pleistocene sedimentary deposit overlain by a debris fan associated with Samang Island, and then by KO tephra (Fig. 9). Bondarenko (1991) identified two separate but chronologically closely spaced Holocene calderas: Kurile Lake caldera, about $7 \mathrm{~km}$ across, located in the southern part of the present Kurile Lake, and Iliinsky caldera, about $6 \mathrm{~km}$ across and cut into the pre-Iliinsky volcano edifice enclosing the Holocene Iliinsky volcano. The two calderas are separated by a ridge, which is older than the $\mathrm{KO}$ eruption deposits, but younger than the basal sediments of the northern bay, and is interpreted to be a part of the pre-Iliinsky edifice. However, the deposits of the Holocene KO eruption do not exhibit any features indicating two separate eruptive centers, and Iliinsky caldera (or part of the caldera) cannot be much younger or much older than Kurile Lake based on the stratigraphic relationship of pre-Iliinsky and Iliinsky products with the KO ignimbrite. That is why Braitseva et al. (1997b) suggested that both depressions are parts of a single complex Holocene caldera, the Kurile Lake-Iliinsky caldera.

We think that the whole Kurile Lake-Iliinsky depression indeed is a result of the $\mathrm{KO}$ eruption. It could have originated as a combination of a caldera collapse within the lake and associated flank failure of the pre-Iliinsky edifice, which stood on the lava plateau, near the eastern scarp of Pauzhetka caldera, and rose above the pre-Holocene depression (Fig. 9). In this case, the underwater ridge, with several abovewater features including Samang Isl., which separates the two calderas described in Bondarenko (1991), 


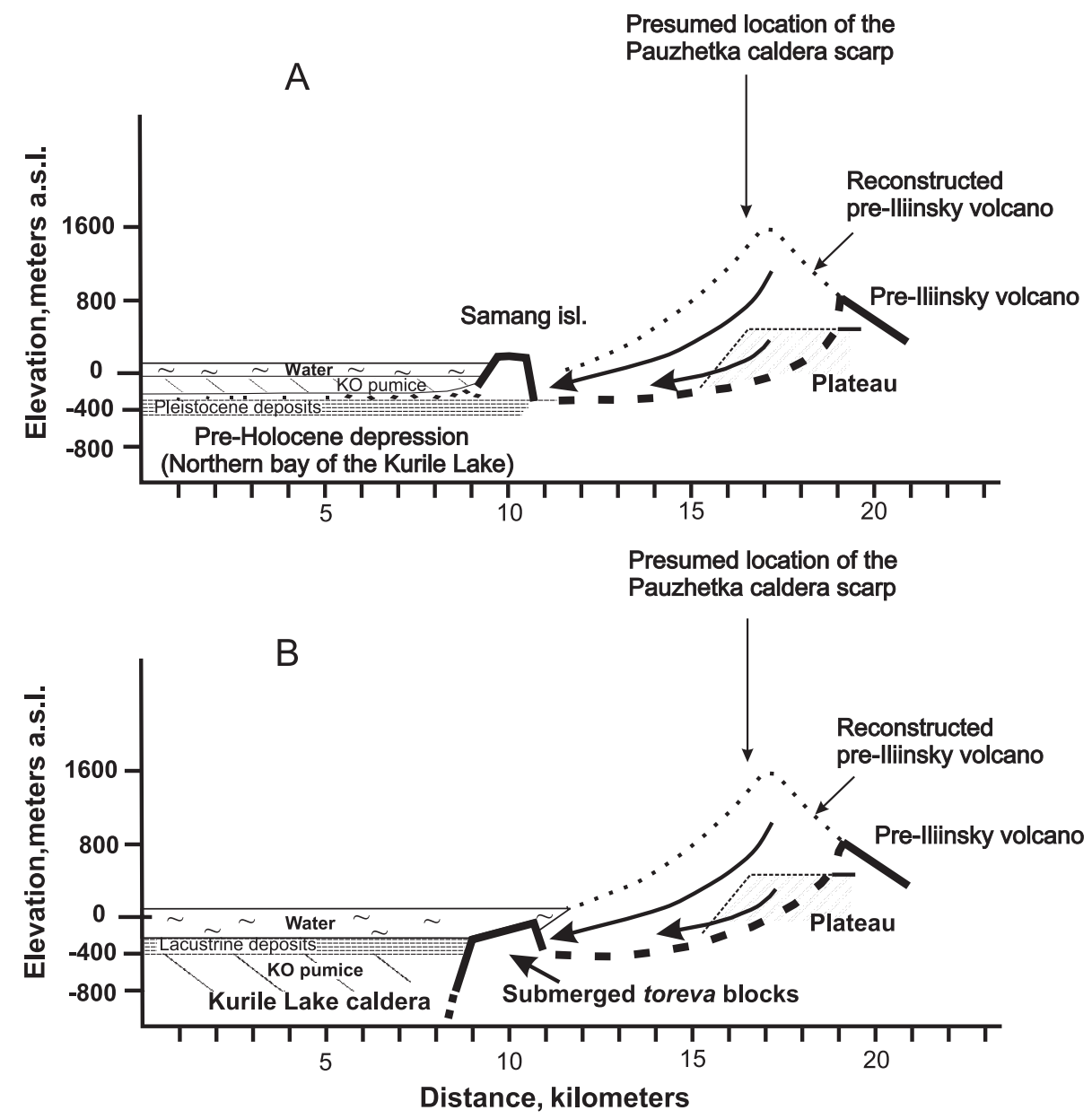

Fig. 9. Schematic profiles showing probable sector collapse of the pre-Iliinsky edifice. (A) Profile through pre-Iliinsky volcano, Samang Island, and northern bay of Kurile Lake. Segments of the pre-Iliinsky edifice and lava plateau collapsed into the Pleistocene depression pre-dating the Kurile Lake caldera, and now form islands in the lake. (B) Profile through pre-lliinsky volcano, submerged ridge presumably composed of preIliinsky blocks, and the Kurile Lake caldera (southern part of the Kurile Lake). Segments of the pre-Iliinsky edifice collapsed into a Pleistocene depression, which then collapsed during formation of the Kurile Lake caldera. Stratigraphy of the lake floor deposits is based on seismic interpretations by Bondarenko (1991).

might be composed of debris from both pre-Iliinsky edifice and lava plateau, and includes huge toreva blocks like those described for Socompa debris avalanche by Francis et al. (1985). Since a debris fan from the supposed slump is overlain by the KO pyroclastic deposits (Bondarenko, 1991), the flank failure may have resulted from strong earthquakes preceding the onset of the eruption. Further studies of the rocks composing Samang and other islands and comparison of them with proposed source areas will help to evaluate this idea.
Studies by Bondarenko (1991) shed light on the structure of the lake basin and enclosed deposits. The underwater caldera is bounded by sub-vertical ring faults (Figs. 6 and 9), which in some places are obscured by later landslides and alluvial fans. A massive pumice deposit from the KO eruption in the central part of the Kurile Lake is more than $400 \mathrm{~m}$ thick and is capped by another $120-160 \mathrm{~m}$ of volcanic and lacustrine sediments. Large slumps such as Cape Glinyany, and the extrusive domes (Serdtze Alaida, Tugumynk, Chayachii) fit stratigraphically 
between massive and reworked pumice deposits indicating an origin at the time of caldera collapse. The two underwater tuff cones confined to the ring faults of the Holocene caldera have the same stratigraphic position. Frequent younger landslides are associated with Iliinsky and especially with Dikii Greben' activity and together with alluvial fans partly mask the caldera faults.

The Kurile Lake caldera represents a gravity and magnetic minimum within regional low gravity values (Masurenkov, 1980; Zubin et al., 1982). Values are lowest on the rhyolite dome islands in the lake. The low gravity field at Kurile Lake is interpreted to be due to a low-density body, possibly a magma chamber about $10 \mathrm{~km}$ across and at a depth of $4 \mathrm{~km}$. The magnetic field is complex but generally low over the lake. The central part of the lake may host some hydrothermal activity (Bondarenko, 1991).

\section{The volume of erupted products}

The KO eruption was the most voluminous Holocene eruption in the Kurile-Kamchatka arc (Braitseva et al., 1995, 1997a; Melekestsev et al., 1998). The 150 $\mathrm{m}$ thick ignimbrite exposures adjacent to Kurile Lake and occurrences of $\mathrm{KO}$ ash fall on mainland Asia, over $1700 \mathrm{~km}$ from the vent, attest to the magnitude of the eruption. Calculation of the eruption volume is difficult as much of the tephra fall and some ignimbrite were spread over the sea. Also, the ignimbrite overlies an irregular topography so its thickness varies considerably. In places younger deposits bury the KO products and in others the $\mathrm{KO}$ has been removed by erosion. Finally, many outcrops remain to be examined.

The volumes of the tephra fall deposits and ignimbrite were initially estimated at $100-120 \mathrm{~km}^{3}$ (Braitseva et al., 1995) and $20-25 \mathrm{~km}^{3}$ (Melekestsev et al., 1974), respectively, for a total eruptive volume of 120-140 $\mathrm{km}^{3}$ (Braitseva et al., 1997a). New and improved mapping of the ignimbrite (Fig. 6) and the tephra fall deposits (Fig. 8) now estimate the volume to be $140-170 \mathrm{~km}^{3}$ (Melekestsev et al., 1998). This erupted volume gives a $70-80 \mathrm{~km}^{3}$ DRE, assuming a magma density of $2.3-2.4 \mathrm{~g} / \mathrm{cm}^{3}$, and the pyroclastic material at $1-1.1 \mathrm{~g} / \mathrm{cm}^{3}$. As Melekestsev et al. (1998) did not provide details on how this volume was estimated, we examine this further below.
The ignimbrite outflow sheet (unit III) covers an estimated area of $1800-1900 \mathrm{~km}^{2}$. The thickness ranges from 1 to $>150 \mathrm{~m}$, and we estimate an average thickness at $15-20 \mathrm{~m}$. This gives a bulk volume of $\leq 40 \mathrm{~km}^{3}$ for the on-land ignimbrite. The thickness of ignimbrite in the coastal exposures west and east of the caldera varies from 2 to $10 \mathrm{~m}$. Based on dispersal patterns of the ignimbrite north and south of the caldera and assuming a symmetrical dispersal, we estimate the underwater part of the ignimbrite outflow sheet may be $\sim 5 \mathrm{~km}^{3}$.

A minimum estimate for the intracaldera deposits is $\sim 18 \mathrm{~km}^{3}$ obtained by multiplying the caldera area (45 $\mathrm{km}^{2}$ ) by a fill thickness of $0.4 \mathrm{~km}$ (Bondarenko, 1991). Pyroclastic fill in the older northern part of the Kurile Lake has a measured thickness of $200 \mathrm{~m}$ (Bondarenko, 1991). Assuming the same thickness in the pre-Iliinsky crater gives a volume of $\sim 13 \mathrm{~km}^{3}$. Therefore a total bulk volume for the ignimbrite outflow, intracaldera and lake filling pyroclastic deposits is $\sim 76 \mathrm{~km}^{3}$.

The pyroclastic fall deposits were a substantial component of the eruption. The fall deposits resulted from minor volumes generated during the initial phase of the eruption (unit I), pumice fallout of the Plinian phase of the eruption (unit II) and co-ignimbrite ash generated during ignimbrite emplacement (unit III). Isopach maps are difficult to reconstruct because much of the tephra fell over the Sea of Okhotsk (Fig. 8). Tephra in a few marine sediment cores (Fig. 8) has been bioturbated (Gorbarenko et al., 2000), and cannot provide thickness data of use in volume calculations. In the lacustrine deposits on mainland Asia the KO tephra varies from a few millimeters to $13 \mathrm{~cm}$ (Anderson et al., 1998) and in places is reworked and once again does not provide good thickness data. A 3-cm-thick tephra layer near the Elikchan Lake in Siberia is $1200 \mathrm{~km}$ from the source. Using this layer we estimate the $3-\mathrm{cm}$ isopach covers $2,009,600 \mathrm{~km}^{2}$. If we cover the obtained area by only a 3-cm-thick ash, we can account for $\sim 60$ $\mathrm{km}^{3}$ of fall tephra. KO tephra has also been identified more than $1700 \mathrm{~km} \mathrm{NW}$ of source in the upper reaches of the Indigirka River (Fig. 8) (Anderson et al., 1998). An ellipse similar to the isopachs in Fig. 8 covering this site would exceed an area of 3 million $\mathrm{km}^{2}$, suggesting the volume is well in excess of $60 \mathrm{~km}^{3}$ and approaches the upper limit of $94 \mathrm{~km}^{3}$ suggested by Melekestsev et al. (1998). 
We believe the estimate of $140-170 \mathrm{~km}^{3}$ total eruptive volume (Melekestsev et al. (1998) may be conservative but the sparcity of data will mean that a good volume estimate is impossible to determine. A volume of $140-170 \mathrm{~km}^{3}$ for the KO eruption makes it comparable to the 1815 Tambora eruptions (Stothers, 1984; Self et al., 1984; Sigurdsson and Carey, 1989). The $150-213 \mathrm{~km}^{3}$ of Tambora ash was estimated from contemporary evidence, and might have yielded far lesser thicknesses if measured in the outcrops some time after the eruption (Self et al., 1984). Even with the large uncertainties in the volume estimates, the $\mathrm{KO}$ eruption must be assigned a VEI index of 7 (Simkin and Siebert, 1994) and thus it ranks among the largest Holocene eruptions like Tambora, Baitoushan (Horn and Schmincke, 2000), Crater Lake (Bacon, 1983), and Kikai caldera (Machida and Arai, 1992).

\section{Age of the KO eruption}

A Holocene age for the $\mathrm{KO}$ eruption and caldera formation was determined in the 1960s based on the stratigraphic position of its tephra above Late Pleis- tocene glacial deposits (Braitseva et al., 1965). Later, radiocarbon dates of 8000 and 8300 years BP were obtained on charred wood and a paleosol underlying the Kurile Lake ignimbrite (Kraevaya, 1967). In the early 1970s, dates of 7600-9500 years BP were obtained, but in most cases the exact stratigraphic position of the samples are unknown (Masurenkov, 1980). This scatter of dates resulted in the assignment of ignimbrites in different valleys to different eruptions, which were envisaged to occur during at least a few hundred years (Masurenkov, 1980).

Further radiocarbon ages for the KO eruption were obtained far from the caldera, mainly on peat and soil containing distal KO ash. Beget et al. (1991) gave a preliminary age of $7500{ }^{14} \mathrm{C}$ years BP for a tephra, later identified as $\mathrm{KO}$ near Elikchan Lake in the Magadan region (Melekestsev et al., 1991). Braitseva et al. (1995) reported new radiocarbon dates from many localities throughout Kamchatka and determined an average age of $7666 \pm 12$ years BP for the $\mathrm{KO}$ eruption. This gave a calendar age within 6530 (6459) 6422 BC (Braitseva et al., 1997a) using the Calib 3.0 program (Stuiver and Reimer, 1993). Two acid peaks with ages of 6470 and $6476 \mathrm{BC}$ were

Table 3

Radiocarbon dates for the Kurile Lake caldera-forming eruption

\begin{tabular}{|c|c|c|c|c|c|c|}
\hline \# & Lab number & Sample & Location & ${ }^{14} \mathrm{C}$ age & $\begin{array}{l}\text { Average }{ }^{14} \mathrm{C} \\
\text { age, years BP }\end{array}$ & $\begin{array}{l}\text { Calibrated age, } \\
\text { years } \mathrm{BC}(2 \sigma \text { range })\end{array}$ \\
\hline 1 & IV-812* & Peat above the KO distal ash & Petropavlovsk-Kamchatsky & $7530 \pm 100$ & & \\
\hline 2 & GIN-6338* & Peat above the $\mathrm{KO}$ distal ash & Avachinsky volcano & $7540 \pm 40$ & & \\
\hline 3 & GIN-8769 & $\begin{array}{l}\text { Branches from charred } \\
\text { peat GIN-8770 }\end{array}$ & $\begin{array}{l}\text { Kurile Lake region, } \\
\text { Figs. } 5 \text { and } 6 \text {, Section } 2\end{array}$ & $7540 \pm 40$ & & \\
\hline 4 & GIN-1047* & $\begin{array}{l}\text { Paleosol, enclosing the } \\
\text { KO distal ash }\end{array}$ & Karymsky volcano & $7550 \pm 80$ & & \\
\hline 5 & IV-828* & Charred paleosol & NW of Zheltovsky & $7570 \pm 100$ & & \\
\hline 6 & GIN-9673 & $\begin{array}{l}\text { Charcoal in the lower part of } \\
\text { the ignimbrite, unit III }\end{array}$ & $\begin{array}{l}\text { Kurile Lake region, } \\
\text { Figs. } 5 \text { and } 6 \text {, Section } 1\end{array}$ & $7590 \pm 40$ & & \\
\hline 7 & GIN-1062* & $\begin{array}{l}\text { Wood from the peat underlying } \\
\text { the KO tephra }\end{array}$ & Kurile Lake region & $7620 \pm 40$ & $7618 \pm 14$ & $6460-6414$ \\
\hline 8 & GIN-8770 & $\begin{array}{l}\text { Charred peat under the } \\
\text { ignimbrite, unit I }\end{array}$ & Fig. 5, Section 2 & $7660 \pm 40$ & & \\
\hline 9 & $\begin{array}{l}\text { GIN-8772a-outer } \\
8772 \text { b-inner } \\
8772 \text { c-middle }\end{array}$ & $\begin{array}{l}\text { Charcoal in the lower part } \\
\text { of the ignimbrite, unit III }\end{array}$ & Fig. 5, Section 2 & $\begin{array}{l}\text { a: } 7660 \pm 50 \\
\text { b: } 7640 \pm 50 \\
\text { c: } 7650 \pm 50\end{array}$ & & \\
\hline 10 & GIN-5252* & Peat under the $\mathrm{KO}$ distal ash & Apacha villaage & $7670 \pm 40$ & & \\
\hline 11 & GIN-6085* & Peat above the KO distal ash & Magadan area & $7670 \pm 100$ & & \\
\hline 12 & GIN-8771 & $\begin{array}{l}\text { Charcoal in the dark-gray part } \\
\text { of the ignimbrite, unit III }\end{array}$ & Fig. 5, Section 2 & $7690 \pm 50$ & & \\
\hline
\end{tabular}

The dates with the GIN code were obtained at the Geological Institute, Moscow; the dates with the IV code-at the Institute of Volcanology, Petropavlovsk-Kamchatsky. Dates marked with an asterisk $(*)$ are from Braitseva et al. (1995). 
identified in the GISP2 ice core (Zielinski et al., 1994) and were suggested as probable correlatives to the Kurile Lake caldera-forming eruption (Braitseva et al., 1997a). Anderson et al. (1998) estimate the age of KO tephra in lake sediment cores and terrestrial exposures $\mathrm{NW}$ of Magadan as $7650 \pm 50{ }^{14} \mathrm{C}$ years BP. A rough estimate of the $\mathrm{KO}$ age was given by Gorbarenko et al. (2002) using deep-sea cores. Their age of $\sim 8.1 \mathrm{ka}$ was based on interpolation between ${ }^{14} \mathrm{C}$ dates of 4.85 and $9.44 \mathrm{ka}$.

Since most of the published radiocarbon dated samples came from distant localities, new samples were collected to confirm and refine the age. Samples included charcoals from the proximal and distal ignimbrite, wood from beneath the ignimbrite, charred soil layers and compressed peats buried by the eruptive deposits. At this time $29{ }^{14} \mathrm{C}$ dates are available (Braitseva et al., 1995; Zaretskaia et al., 2001) and 14 are considered reliable (Table 3, Fig. 4). The 14 give an average radiocarbon age of $7618 \pm 14$ years BP, calculated using the procedure of Stuiver et al. (1998). This gives a calendar age of BC 6460-6414, using the Incal98 calibration curve (Stuiver et al., 1998) and the OxCal v3.8 program (Bronk Ramsey, 1995, 2001).

\section{An eruption synopsis}

The KO eruption was preceded by over 1500 years of quiescence as shown by a 5-20 cm thick paleosol underlying the KO deposits (Ponomareva et al., 2001). The only Holocene precursor to the catastrophic eruption may have been a small explosive eruption of dacitic pumice from what is now the northern part of Kurile Lake. We speculate that earthquakes accompanying magma ascent prior to and during the eruption probably caused sector collapse and landslides from the pre-Iliinsky volcanic edifice and the scarps of the old Pauzhetka caldera (Fig. 9) into a protoKurile Lake.

The KO eruption began with phreatoplinian activity, presumably through a proto-Kurile Lake, which deposited rhyolitic vitric fine ash and a sequence of pyroclastic density current deposits (ignimbrites) (unit I). The initial phreatoplinian ash covered an area $>500$ $\mathrm{km}^{2}$ and had its greatest thicknesses in the Ozernaya River valley. It was dispersed along a W-NW trending axis (Fig. 2). The initial ignimbrites probably partially filled the proto-Kurile Lake and associated pre-Holocene depression and were ponded in some radial valleys. They reached elevations of $250 \mathrm{~m}$ a.s.1. and traveled at least $9 \mathrm{~km}$ from vent (Fig. 2). This initial activity, presumably, helped trigger the catastrophic plinian eruption by removing some magma from the chamber thus decreased pressure and promoted vesiculation.

The eruption changed to a sustained plinian column, as the proto-Kurile lake dried out and/or the vent emerged above the water level, generating pumice fall deposits. Tephra fell over much of the southern Kamchatka Peninsula (Fig. 8) and exceeds $5 \mathrm{~m}$ in thickness in proximal localities (Fig. 5, Section 6). The eruptive column was dispersed by wind northwest across the Sea of Okhotsk. The plinian fall deposits form a single continuous unit implying a sustained eruptive column. Locally the pumice fall contains fine ash layers interpreted as being deposited by rain flushing. Pumice bombs and lapilli have rhyolitic to dacitic compositions. Lithic-rich zones in the plinian pumice fall of unit II probably reflect widening of the vent. Widening would have resulted in column collapse and formation of pyroclastic density currents which deposited the ignimbrites of unit III.

The final stage of the KO eruption is characterized by ignimbrite and cross-bedded (surge) deposits. Ignimbrite ponded in the valleys and formed a thin veneer on the adjacent ridges and plateaus (Fig. 6) up to $50 \mathrm{~km}$ from vent. The ignimbrite formed a single cooling unit and demonstrated transition from rhyolite to basaltic andesite, and back again to rhyolite during the eruption. The occurrence of lag breccia within the lower rhyolitic ignimbrite suggests the eruption transitioned to a ring vent phase. This occurred during the eruption of the silicic ignimbrite but may have promoted eruption of mafic magma from deeper in the chamber before reverting back to silicic magma. The absence of mafic ignimbrite west of the caldera may indicate an asymmetrical magma chamber or asymmetrical draining of the chamber.

Water was likely to have been an important component during ignimbrite formation and deposition. Accretionary lapilli are common in well defined beds within the ignimbrite and are likely to have resulted from water picked up during the eruption from groundwater or remnants of the proto-Kurile Lake. 
Fossil fumaroles are another common feature in the ignimbrite and suggest emplacement over rivers and wet ground. Pumice concentration zones and finesdepleted ignimbrite are evidence of fluidization of the pyroclastic density current (Wilson, 1985) and this was likely enhanced by the water in the pyroclastic density current and from underlying wet sources.

Large co-ignimbrite ash (phoenix) clouds were likely generated when the ignimbrite reached the sea on both sides of the peninsula. This would account for the widespread distribution of fine ash which constitutes at least half of the distal fall deposits.

Large slumps, from the inner scarps of the caldera and surrounding areas, overlie the eruptive sequence. Slumping and collapse was therefore continuing after caldera collapse and apparently coincides with formation of cinder cones and extrusive domes inside and outside the caldera (Bondarenko, 1991).

The eruption produced at least $140-170 \mathrm{~km}^{3}$ of tephra or $70-80 \mathrm{~km}^{3}$ of magma. The simple eruptive sequence, lack of depositional breaks between the units, and the uniform dispersal pattern of the fall ash indicate that the eruption had a short duration. Because of its size the KO eruption may have influenced global weather patterns in a way similar to Tambora (Stothers, 1984).

The eruption was undoubtedly an ecological catastrophe for Kamchatka, due to the dispersal of large amounts of tephra over the peninsula (Figs. 6 and 8). Ignimbrite and thick fall deposits cover 5000-6000 $\mathrm{km}^{2}$ and would have resulted in total devastation. Fall deposits over $5 \mathrm{~cm}$ thick cover an additional area of $15,000 \mathrm{~km}^{2}$ and would have killed vegetation. Only outside the $5 \mathrm{~cm}$ isopach may the vegetation have benefited from the ash as a source of useful nutrients. We can roughly estimate the time necessary for vegetation recovery from the oldest dates on the organic matter overlying the KO tephra. In distal areas near Avachinsky and Karymsky volcanoes (Braitseva et al., 1995) and in the Magadan region (Melekestsev et al., 1991) they are virtually similar to the youngest dates of 7540-7670 years BP from below the KO deposits indicating minor influence of the $\mathrm{KO}$ eruption on the vegetation. In contrast, the radiocarbon dates on vegetation overlying $\mathrm{KO}$ deposits are substantially younger closer to the Kurile Lake caldera. The oldest radiocarbon ages of vegetation overlying the KO deposits are $\sim 7200$ years BP and only 6300 years BP, 50-150 and $30 \mathrm{~km}$ from the caldera, respectively (Ponomareva et al., 2001).

Eruption of Iliinsky volcano followed soon after the $\mathrm{KO}$ eruption. The similarity of the $\mathrm{K}_{2} \mathrm{O}$ versus $\mathrm{SiO}_{2}$ trends (Fig. 10, Table 1) of the Iliinsky rocks and the KO pyroclastic deposits, suggest a genetic relationship. Iliinsky sits in a depression which may be the crater of a pre-Iliinsky volcano. Lava flows and pyroclastic deposits from Illinsky overlie the KO ignimbrite. Eruptions of Illinsky between 7600 and $\sim 6500{ }^{14} \mathrm{C}$ years BP produced basaltic andesite to dacite lava flows and tephra. Following a 1700 year repose period, Iliinsky commenced explosive activity $\sim 4800{ }^{14} \mathrm{C}$ years $\mathrm{BP}$, which became more intense $\sim 4000{ }^{14} \mathrm{C}$ years BP. The volcanic cone reached its modern shape and height about $1900{ }^{14} \mathrm{C}$ years BP, and then entered another repose period. In 1901, a phreatic eruption formed a large crater on the eastern slope of the volcano (Fig. 1), and may herald the start of a new period of activity (Ponomareva et al., 2001).

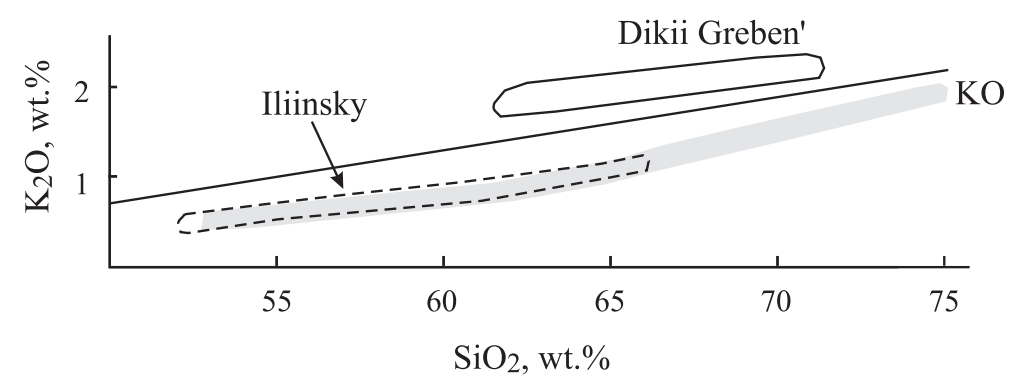

Fig. 10. $\mathrm{K}_{2} \mathrm{O}-\mathrm{SiO}_{2}$ diagram, comparing the composition of $\mathrm{KO}$ erupted products with those of Iliinsky and Dikii Greben' volcanoes. The diagram is based on the representative analyses in Table 1, unpublished analyses by the authors and supplemented by analyses of Dikii Greben from Bindeman and Bailey (1994). All analyses were recalculated to $100 \%$, volatile-free. 
The largest eruptions from Iliinsky produced up to 1 $\mathrm{km}^{3}$ of tephra which was spread $\sim 50 \mathrm{~km}$ from the volcano.

Dikii Greben' also formed soon after the KO eruption and caldera collapse. The volcano is composed of rhyodacite and dacite with subordinate andesite (Bindeman and Bailey, 1994), which differs geochemically from the rhyodacite-andesite of the KO eruption (Fig. 10). It is a large extrusive massif, consisting of a main dome (Mt. Nepriyatnaya), several smaller domes, associated ignimbrites and lava flows, and large landslide (avalanche) deposits. The volcano was formed immediately west of the KO caldera rim. An initial pumice fall deposits from Dikii Greben' directly overlie the slightly reworked top of the KO ignimbrite. An ignimbrite erupted shortly after the fall fills slightly eroded surfaces on the KO ignimbrite. The time interval between the Dikii Greben' and KO eruptions was too short to allow soil formation and we estimate it was $<100$ years. Dikii Greben' formed in three distinct episodes $\sim 7500,4200$, and $1600{ }^{14} \mathrm{C}$ years BP (Ponomareva et al., 1995). Dikii Greben' occupies an area of more than $100 \mathrm{~km}^{2}$ and has a volume of about $6 \mathrm{~km}^{3}$.

Islands in the Kurile Lake have two origins. Some are post-caldera extrusive domes (e.g. Serdtze Alaida, Chayachii), whereas some are collapsed blocks from the pre-Iliinsky volcano and lava plateau. Seismic profiling suggests that most of the extrusive domes and submerged pyroclastic cones formed immediately after caldera collapse, since their deposits sit on caldera fill deposits and underlie lacustrine sediments (Bondarenko, 1991). Serdtze Alaida ("Heart of Alaid") is an extrusive dome rising more than 300 $\mathrm{m}$ from the lake floor and forms an island in the middle of the caldera. It is composed of dacite geochemically similar to dacites in the KO tephra.

The duration of the eruptions, beginning with the initial KO phreatoplinian eruptions till formation of Iliinsky and Dikii Greben' volcanoes, may have been only a few decades. This eruptive episode was the strongest pulse of volcanic activity observed in Kamchatka during the Holocene. It was also the most important constituent of "a century" of volcanic catastrophes in Kamchatka (6600-6400 BC), when numerous eruptions produced lava and tephra deposits with a total bulk volume of at least $245-292 \mathrm{~km}^{3}$ (Melekestsev et al., 1998). The events during this period vividly attest to the irregular character of the volcanic process and provide a scale for possible future volcanic catastrophes in the island arc environment.

\section{Acknowledgements}

The research described in this paper was supported in part by the Russian Foundation for Basic Research (grants \#00-05-64299 and \#02-05-64991); NATORussia Collaborative grant JSTC.RCLG.978989, and by the National Science and Technology Program "Global Environmental and Climatic Change". Field work was funded by grants 5663-96, 5926-97 and 6215-98 from the National Geographic Society. Philip Kyle acknowledges support from the US National Science Foundation, which provided sabbatical leave support enabling him to work on this manuscript. Section 9 was measured by Joanne Burgeois and Tatiana Pinegina thanks to support from RFBR grant \# 00-05-64697; most distal sample of KO tephra at Elikchan Lake was collected by Patricia Anderson and Anatolii thanks to RFBR grant \# 03-05-64294. We thank our colleagues for providing us with these data. Financial support from NSF grant \#EAR-0125787 to Joanne Burgeois allowed Vera Ponomareva to accomplish her work on the manuscript. The authors are grateful to Stephen Self and Tom Miller for thoroughly reviewing the manuscript and their valuable comments and suggestions.

\section{References}

Anderson, P.M., Lozhkin, A.V., Belaya, B.V., 1998. Younger Dryas in western Beringia (northeastern Siberia). In: Simakov, K.V. (Ed.), Environmental Changes in Beringia During the Quaternary. North East Interdisciplinary Research Institute, Far East Branch, Russian Academy of Sciences, Magadan, pp. 28-44 (in Russian).

Bacon, C.R., 1983. Eruptive history of Mount Mazama and Crater Lake caldera, Cascade range, USA. J. Volcanol. Geotherm. Res. 18, 57-115.

Beget, J.T., Hopkins, D.M., Lozhkin, A.V., Anderson, P.M., Eisner, W.R., 1991. The newly discovered Elikchan tephra on the mainland of Soviet Asia. Abstr. Programs - Geol. Soc. Am., 62.

Bindeman, I.N., Bailey, J.C., 1994. A model of reverse differentiation at Dikii Greben' volcano, Kamchatka: progressive basic magma vesiculation in a silicic magma chamber. Contrib. Mineral. Petrol. 117, 263-278. 
Bondarenko, V.I., 1991. Seismic reflection profiling in Lake Kurilskoe. Volcanol. Seismol. 12 (4), 533-548.

Braitseva, O.A., Melekestsev, I.V., 1990. Eruptive history of Karymsky volcano, Kamchatka, USSR, based on tephra stratigraphy and ${ }^{14} \mathrm{C}$ dating. Bull. Volcanol. 53, 195-206.

Braitseva, O.A., Kraevaya, T.S., Sheimovich, V.S., 1965. On the origin of the Kurile Lake and pumices of this regionVoprosy Geografii Kamcatki (Problems of the Geography of Kamchatka) vol. III. Far East Bank Publishers, Petropavlovsk-Kamchatskij, pp. 49-57 (in Russian).

Braitseva, O.A., Melekestsev, I.V., Ponomareva, V.V., Sulerzhitsky, L.D., 1995. The ages of calderas, large explosive craters and active volcanoes in the Kuril-Kamchatka region, Russia. Bull. Volcanol. 57 (6), 383-402.

Braitseva, O.A., Melekestsev, I.V., Ponomareva, V.V., Kirianov, V.Yu., 1996. The caldera-forming eruption of Ksudach volcano about cal. AD 240, the greatest explosive event of our era in Kamchatka. J. Volcanol. Geotherm. Res. 70 (1-2), 49-66.

Braitseva, O.A., Sulerzhitsky, L.D., Ponomareva, V.V., Melekestsev, I.V., 1997a. Geochronology of the greatest Holocene explosive eruptions in Kamchatka and their imprint on the Greenland glacier shield. Trans. (Doklady) of the Russian Academy of Sciences. Earth Sci. Sections 352 (1), 138-140.

Braitseva, O.A., Ponomareva, V.V., Sulerzhitsky, L.D., Melekestsev, I.V., Bailey, J., 1997b. Holocene key-marker tephra layers in Kamchatka, Russia. Quat. Res. 47, 125-139.

Braitseva, O.A., Bazanova, L.I., Melekestsev, I.V., Sulerzhitsky, L.D., 1998. Largest Holocene eruptions of Avachinsky volcano, Kamchatka. Volcanol. Seismol. 20, 1-27.

Bronk Ramsey, C., 1995. Radiocarbon calibration and analysis of stratigraphy: the OxCal program. Radiocarbon 37 (2), 425-430.

Bronk Ramsey, C., 2001. Development of the Radiocarbon Program OxCal. Radiocarbon 43 (2A), 355-363.

Bursik, M.I., Melekestsev, I.V., Braitseva, O.A., 1993. Most recent fall deposits of Ksudach volcano, Kamchatka, Russia. Geophys. Res. Let. 20 (17), 1815-1818.

Cas, R.A.F., Wright, J.V., 1987. Volcanic Successions. Chapman and Hall, New York, NY.

Druitt, T.H., Sparks, R.S.J., 1981. A proximal ignimbrite breccia facies on Santorini, Greece. J. Volcanol. Geotherm. Res. 13, 147-171.

Florensky, I.V., Bazanova, L.I., 1991. Cenozoic volcanism in southeastern Kamchatka (Beregovoi Range). Volcanol. Seismol. 11 (6), 796-812.

Francis, P.W., Gardeweg, M., O’Callaghan, L.J., Ramirez, C.F., Rothery, D.A., 1985. Catastrophic debris avalanche deposit of Socompa volcano, north Chile. Geology 13, 600-603.

Geist, E.L., Scholl, D.W., 1994. Large-scale deformation related to the collision of the Aleutian Arc with Kamchatka. Tectonics 13, 538-560.

Gorbarenko, S.A., Derkachev, A.N., Astakhov, A.S., Southon, J.R., Shapovalov-Chuprynin, V.V., Nürnberg, D., 2000. Lithostratigraphy and tephrochronology of the Upper Quaternary sediments of the Sea of Okhotsk. Pac. Geol. 19 (2), 58-72.

Gorbarenko, S.A., Nürnberg, D., Derkachev, A.N., Astakhov, A.S., Southon, J.R., Kaiser, A., 2002. Magnetostratigraphy and teph- rochronology of the upper Quaternary sediments in the Okhotsk sea: implication of terrigenous, volcanogenic and biogenic matter supply. Mar. Geol. 183, 107-129.

Gorbatov, A., Kostoglodov, V., Suarez, G., Gordeev, E.I., 1997. Seismicity and structure of the Kamchatka subduction zone. J. Geophys. Res. 102 (B8), 17883-17898.

Horn, S., Schmincke, H.-U., 2000. Volatile emission during the eruption of Baitoushan Volcano (China/Korea) ca.969 AD. Bull. Volcanol. 61, 537-555.

Kraevaya, T.S., 1967. New data on the recent pumice deposits of the Kurile Lake region. Voprosy Geografii Kamcatki (Problems of Kamchatka Geography) 5, 128-129 (in Russian).

Kyle, P.R., Rinkleff, P., Chen, Ch.-H., Bindeman, I., Ponomareva, V.V., Dunbar, N., Dirksen, O., in preparation. The $7600\left({ }^{14} \mathrm{C}\right)$ year BP Kurile Lake caldera-forming eruption, Kamchatka, Russia: Petrology.

Machida, H., Arai, F., 1992. Atlas of Tephra in and Around Japan. Tokyo Univ. Press, Tokyo.

Masurenkov, Yu.P. (Ed.), 1980. Long Existing Center of Endogenic Activity in South Kamchatka. Nauka, Moscow, 172 pp. (in Russian).

Melekestsev, I.V., Braitseva, O.A., Erlich, E.N., Kozhemyaka, N.N., 1974. Volcanic mountains and plains. In: Luchitsky, I.V. (Ed.), Kamchatka, Kurile and Commander Islands. Nauka, Moscow, pp. 162-234. (in Russian).

Melekestsev, I.V., Braitseva, O.A., Ponomareva, V.V., 1990. Holocene activity dynamics of Mutnovskii and Gorelyi volcanoes and the volcanic risk for adjacent areas (as indicated by tephrochronology studies). Volcanol. Seismol. 9 (3), 337-362.

Melekestsev, I.V., Glushkova, O.Yu., Kirianov, V.Yu., Lozhkin, A.V., Sulerzhitsky, L.D., 1991. Age and origin of Magadan ashes. Trans. (Doklady) of the Russian Academy of Sciences. Earth Sci. Sections 317 (5), 1188-1192.

Melekestsev, I.V., Dvigalo, V.N., Kiryanov, V.Yu., Kurbatov, A.V., Nesmachnyi, I.A., 1994. Ebeko volcano, Kuril Islands: Eruptive history and potential volcanic hazards, Part I. Volcanol. Seismol. 15 (3), 339-354.

Melekestsev, I.V., Braitseva, O.A., Ponomareva, V.V., Sulerzhitsky, L.D., 1996. Holocene catastrophic caldera-forming eruptions of Ksudach volcano, Kamchatka. Volcanol. Seismol. 17, 395-421.

Melekestsev, I.V., Braitseva, O.A., Ponomareva, V.V., Sulerzhitsky, L.D., 1998. A century of volcanic catastrophes in the KurileKamchatka region in Early Holocene time. In: Dobretsov, N.L., Kovalenko, V.I. (Eds.), Global Environmental Change. Sibir' Division of RAS Publishing House, Novosibirsk, pp. 146-152 (in Russian).

Melekestsev, I.V., Dirksen, O.V., Girina, O.A., 1999. A giant landslide-explosion cirque and a debris avalanche at Bakening volcano, Kamchatka. Volcanol. Seismol. 20 (3), 265-280.

Miller, T.P., Smith, R.L., 1987. Late Quaternary caldera-forming eruptions in the eastern Aleutian arc, Alaska. Geology 15, 434-438.

Miller, T.P., McGimsey, R.G., Richter, D.H., Riehle, J.R., Nye, C.J., Yount, M.E., Dumoulin, J.A., 1998. Catalog of the historically active volcanoes of Alaska. Open-File Rep.(U. S. Geol. Surv.) OF 98-0582 (104 pp.). 
Novograblenov, P.T., 1932. The catalogue of volcanoes of Kamchatka. Isvestiya Gos. Geogr. Sci. XIY-1, 88-99 (in Russian).

Piip, B.I., 1947. Reconnaissance geological studies in South Kamchatka. Trudy (Transactions) of the Kamchatka Volcanological Station of the USSR Academy of Sciences. USSR Academy of Sciences Publisher, Moscow, vol. 3, pp. 89-134.

Ponomareva, V.V., Dirksen, O.V., Sulerzhitsky, L.D., 1995. Eruptive history of Dikiy Greben volcano-the largest Holocene extrusive edifice in Kamchatka, Russia. Abstracts Int. Workshop on Volcanoes Commemorating the 50th Anniversary of Mt. Showa-Shinzan, p. 159.

Ponomareva, V.V., Sulerzhitsky, L.D., Dirksen, O.V., Zaretskaia, N.E., 2001. Holocene paleosols as records of intervals of volcanic quiescence in the Kurile Lake region, South Kamchatka. In: Juvigné, E., Raynal, J.P. (Eds.), Tephras, Chronology, Archaeology. Les Dossiers de 1'Archéo-Logie, vol. 1. CDERAD Ed., Goudek, 91-100.

Rinkleff, P., 1999. Petrologic evolution and stratigraphy of the eruptive products from the $7.7 \mathrm{ka}\left({ }^{14} \mathrm{C}\right)$ Kurile Lake caldera eruption, southern Kamchatka, Russia. MS Thesis. Dept. Earth Environmental Sci., New Mexico Institute of Mining and Technology, $198 \mathrm{pp}$.

Self, S., 1983. Large scale phreatomagmatic silicic volcanism: a case study from New Zealand. J. Volcanol. Geotherm. Res. 17, 433-469.

Self, S., Sparks, R.S.J., 1978. Characteristics of widespread pyroclastic deposits formed by the interaction of silicic magma and water. Bull. Volcanol. 41, 196-212.

Self, S., Rampino, M.R., Newton, M.S., Wolff, J.A., 1984. Volcanological study of the great Tambora eruption of 1815. Geology 12 (11), 659-663.

Seliangin, O.B., Ponomareva, V.V., 1999. Gorelovsky volcanic center, South Kamchatka: structure and evolution. Volcanol. Seismol. 21 (2), 163-194.

Sigurdsson, H., Carey, S., 1989. Plinian and co-ignimbrite tephra fall from the 1815 eruption of Tambora volcano. Bull. Volcanol. 51, 243-270.

Simkin, T., Siebert, L., 1994. Volcanoes of the World, Second edition. Geoscience Press, Tucson, AZ.

Sparks, R.S.J., Walker, G.P.L., 1977. The significance of vitricenriched air fall ashes associated with crystal enriched ignimbrites. J. Volcanol. Geotherm. Res. 2, 329-341.

Stothers, R.B., 1984. The great Tambora eruption of 1815 and its aftermath. Science 224, 1191-1198.

Stuiver, M., Reimer, P.J., 1993. Extended ${ }^{14} \mathrm{C}$ data base and revised CALIB $3.0{ }^{14} \mathrm{C}$ age calibration program. Radiocarbon $35,215-$ 230.

Stuiver, M., Reimer, P.J., Bard, E., Beck, J.W., Burr, G.S., Hughen, K.A., Kromer, B., McCormac, G., van der Plicht, J., Spurk, M., 1998. INTCAL98 Radiocarbon Age Calibration, 24,000-0 cal BP. Radiocarbon 40 (3), 1041-1085.

Volynets, O.N., Ponomareva, V.V., Braitseva, O.A., Melekestsev, I.V., Chen, Ch.H., 1999. Holocene eruptive history of Ksudach volcanic massif, South Kamchatka: evolution of a large magmatic chamber. J. Volcanol. Geotherm. Res. 91, 23-42.

Wilson, C.J.N., 1985. The Taupo eruption, New Zealand: II. The Taupo ignimbrite. Philos. Trans. R. Soc. Lond. Ser. A 314 (1529), 229-310

Zaretskaia, N.E., Ponomareva, V.V., Sulerzhitsky, L.D., Dirksen, O.V., 2001. Radiocarbon dating of the Kurile Lake caldera eruption (South Kamchatka, Russia). Geochronometria 20, 95-102.

Zielinski, G.A., Mayewski, P.A., Meeker, L.D., Whitlow, S., Twickler, M.S., Morrison, M., Meese, D.A., Gow, A.J., Alley, R.B., 1994. Record of volcanism since 7000 B.C. from the GISP2 Greenland ice core and implications for the volcano-climate system. Science 264 (5161), 948-952.

Zubin, M.I., Nikolaev, A.S., Sheimovich, V.S., 1982. New data on the origin of the Kurile Lake depression, Kamchatka. Volcanol. Seismol. 1, 85-88 (in Russian). 